\title{
Sistem Informasi Perhitungan Stok Barang Per Gudang pada PT.Dima Habadi Menggunakan Metode Double Exponential Smoothing
}

\author{
${ }^{1}$ Suhendi, ${ }^{2}$ Imron Nugraha, ${ }^{3}$ Nurul Hilda Syani Putri \\ ${ }^{1,2,3}$ STT Indonesia Tanjungpinang \\ Jln. Pompa Air No. 28 Tanjungpinang Kepulauan Riau Indonesia \\ ${ }^{1}$ suhendiyangfei@gmail.com \\ 2imron_nugraha05@yahoo.com \\ ${ }^{3}$ nurulhildasp14@gmail.com
}

\begin{abstract}
Intisari - Penelitian ini ditekankan pada permasalahan pada pencatatan transaksi pada PT.DIMA HABADI yang masih memiliki kendala dalam membuat laporan stok barang saat sedang melakukan pencatatan transaksi yang sangat banyak. Proses laporan stok barang yang masih memerlukan waktu yang cukup lama, karena pencatatan transaksi yang masih manual dan harus di crosscheck kembali yang relative banyak. Maka dari itu tujuan dari penelitian ini berupaya supaya dapat memperbaiki kelemahan pencatatan secara manual, dan juga dapat mempermudah dalam membuat laporan stok barang. Metode penelitian yang digunakan adalah studi literatur dan pengumpulan data melalui wawancara mendalam dan pengamatan langsung untuk mencermati cara kerja pencatatan transaksi yang sedang berjalan. Metodologi pengembangan sistem adalah menggunakan "Model Air Terjun" dan diimplementasikan melalui bahasa pemrograman Visual Studio 2015 dan SQL Server 2012 sebagai database.
\end{abstract}

Kata kunci - aplikasi, pencatatan transaksi, laporan stok barang, PT.DIMA HABADI.

Abstract - This research focused on the problems in the sense of recording transactions on PT.DIMA HABADI who still have problems in stock reporting while doing the recording of transactions very much. Stock reporting process that still requires a long time, because the manual recording of transactions and should crosscheck back relatively much. Thus the purpose of this research cope in order to improve the weaknesses recording manually, and also to facilitate the stocking statements. The method used is the study of literature and data collection through in-depth interviews and direct observation to examine the workings of recording the transaction in progress.

System development methodology is the use of "Waterfall Model" and is implemented through the programming language Visual Studio 2013 and SQL Server 2012 as the database.

Keywords - application, recording transactions, stock reporting, PT.DIMA HABADI.

\section{PENDAHULUAN}

\section{A. Latar Belakang}

Perkembangan teknologi saat ini begitu cepat. Salah satunya adalah teknologi informasi. Dengan adanya teknologi informasi, kita tidak hanya memperoleh data informasi dengan mudah dan cepat, namun keakuratan data juga harus deperhatikan. Persediaan barang (Inventory) atau peryimpanan barang ini adalah hal yang sangat dibutuhkan pada perusahaan yang melakukan proses pemesanan barang setiap hari. Keakuratan data dan informasi barang sangat penting karena akan dijadikan sebuah pelaporan informasi pembukuan.

PT. Dima Habadi merupakan perusahaan yang bergerak di bidang retail, supermarket, delimart, minimart dan metode rata-rata yang memberi bobot lebih besar pada demand terakhir dan lebih andal untuk menganalisa data yang menunjukkan trend.

Selain itu dalam pencatatan masih menggunakan sistem manual, semua transaksi persediaan barang dicatat dan kemudian dilaporkan, dengan adanya sistem seperti ini express. Salah satu tugas pokoknya yaitu memanajemen persediaan barang untuk kebutuhan outlet sehari-hari, dikarenakan barang-barang tersebut tidak dapat bertahan untuk waktu yang lama, sehingga jika penerimaan barang terlalu banyak akan berdampak pada kualitas barang tersebut, jika terlalu sedikit penerimaannya maka akan menyebabkan kerugian pada outlet dan juga kepada tingkat kepercayaan para konsumen terhadap outlet tersebut. Oleh karena itu dibutuhkan metode perhitungan peramalan jumlah pengorderan barang dari masing-masing outlet untuk penerimaan barang kedepannya.

Peramalan dalam pengorderan barang umumnya menggunakan metode Double Exponential Smoothing yaitu banyak permasalahan yang akan terjadi terutama pada sistem laporan yang manual.

Untuk menghindari percatatan persediaan yang manual, dibutuhkan suatu layanan sistem informasi persediaan barang yang dapat mempermudah manajemen perusahaan memperoleh informasi tentang laporan-laporan yang tersimpan dalam suatu database pengolahan persediaan 
barang mulai dari pemesanan barang dari outlet maupun pemesanan barang sampai ke proses supplier.

Dalam setiap perusahaan laporan persediaan barang sangatlah penting karena dengan informasi yang akurat dapat mengambil sebuah keputusan yang tepat. Oleh karena itu, untuk meningkatkan efisiensi dan mempercepat layanan dalam memberikan informasi yang akurat, maka penulis melakukan penelitian "SISTEM INFORMASI PERHITUNGAN STOK BARANG PER GUDANG PADA PT.DIMA HABADI MENGGUNAKAN METODE DOUBLE EXPONENTIAL SMOOTHING"

\section{B. Identifikasi Masalah}

Berdasarkan latar belakang masalah di atas maka dapat ditarik beberapa permasalahan yang timbul, antara lain :

1. Pemesanan barang masih secara manual sehingga sering kali terjadi kelebihan atau kekurangan barang di masing-masing tempat.

2. Perhitungan stok barang per gudang masih manual.

3. Pengiriman barang ke outlet tidak terbagi rata.

4. Pengiriman barang tidak lengkap atau tidak sesuai dengan yang dipesan.

5. Perhitungan pembelian dan penjualan barang masih manual.

6. Pembuatan laporan penjualan dan pembelian relatif lama karena masih berupa arsipan.

\section{Rumusan Masalah}

Berdasarkan identifikasi masalah di atas, maka dapat dirumuskan masalah sebagai berikut :

Bagaimana membangun sebuah sistem yang mampu mengolah data dan menyajikan laporan pembelian, penjualan dan persediaan barang?

D. Batasan Masalah

Berdasarkan dengan latar belakang yang telah diuraikan, agar pembahasan ini tidak meluas, dibatasi halhal sebagai berikut :

1. Sistem dapat mengolah data pembelian dan penjualan barang saja.

2. Sistem dapat mengirim barang berdasarkan permintaan outlet.

3. Sistem dapat melakukan pembuatan laporan stock per gudang

A. Sistem

\section{LANDASAN TEORI}

Suatu sistem sangatlah dibutuhkan dalam suatu perusahaan atau instansi pemerintahan, karena sistem sangatlah menunjang terhadap kinerja perusahaan atau instansi pemerintah, baik yang berskala kecil maupun besar. Supaya dapat berjalan dengan baik diperlukan kerjasama di antara unsur-unsur yang terkait dalam sistem tersebut.

Ada berbagai pendapat yang mendefinisikan pengertian sistem, seperti di bawah ini :

1. Jogiyanto Hartono
"Suatu sistem dapat didefinisikan sebagai suatu kesatuan yang terdiri dari dua atau lebih komponen atau subsistem yang berinteraksi untuk mencapai suatu tujuan" 2. Tata Sutabri

"Sistem terdiri dari struktur dan proses. Struktur sistem merupakan unsur-unsur yang membentuk sistem tersebut. Sedangkan proses sistem menjelaskan cara kerja setiap unsur sistem tersebut dalam mencapai tujuan sistem"

Syarat-syarat sistem adalah :

1. Sistem harus dibentuk untuk menyeleasikan tujuan.

2. Elemen sistem harus mempunyai rencana yang ditetapkan.

3. Adanya hubungan diantara elemen sistem

4. Unsur dasar dari proses (arus informasi, energy dan material) lebih penting dari pada elemen sistem.

5. Tujuan organisasi lebih penting dari tujuan elemen klasifikasi sistem.

B. Karakteristik Sistem

Selain itu sebuah sistem juga memiliki karakteristik atau sifat-sifat tertentu, yang merincikan bahwa hal tersebut bisa dikatakan sebagai suatu sistem.

Adapun karakteristik yang dimaksud adalah sebagai berikut:

1. Komponen Sistem (Components): Suatu sistem terdiri dari sejumlah komponen yang saling berinteraksi, yaitu saling bekerjasama membentuk satu kesatuan. Setiap subsistem memiliki sifat-sifat dari sistem untuk menjalankan suatu fungsi tertentu dan mempengaruhi suatu proses sistem secara keseluruhan.

2. Batasan Sistem (Boundary): Merupakan daerah yang membatasi antara sistem dengan sistem yang lain atau sistem dengan lingkungan luarnya. Batasan sistem ini memungkinkan suatu sistem dipandang sebagai satu kesatuan yang tidak dapat dipisah-pisahkan.

3. Lingkungan Luar Sistem (Environtment): Lingkungan luar sistem bersifat menguntungkan dan dapat bersifat merugikan sistem tersebut. Lingkungan luar yang menguntungkan merupakan energi bagi sistem tersebut. Dengan demikian, lingkungan luar tersebut harus tetap dijaga dan dipelihara. Lingkungan luar yang merugikan harus dikendalikan. Kalau tidak, maka akan mengganggu kelangsungan hidup sistem terebut.

4. Penghubung Sistem (Interface) : Penghubung Sistem merupakan media penghubung antara satu subsistem dengan subsistem lainnya. Melalui penghubung ini memungkinkan sumber - sumber daya mengalir dari satu subsistem akan menjadi masukan (input) untuk subsistem lainnya dengan melalui penghubung.

5. Masukan Sistem (Input) :Masukan Sistem adalah energi yang dimasukkan kedalam sistem. Masukan dapat berupa masukan perawatan (maintenance input) yaitu energi yang dimasukkan supaya sistem tersebut dapat beroperasi, dan masukan sinyal (signal input) yaitu 
energi yang diproses untuk didapatkan keluaran atau informasi.

6. Keluaran Sistem (Output): Keluaran Sistem adalah hasil dari energi yang diolah dan diklasifikasikan menjadi keluaran yang berguna dan sisa pembuangan. Keluaran dapat berupa masukan untuk subsistem yang lain.

7. Pengolah Sistem (Process): Suatu sistem dapat mempunyai suatu bagian pengolah yang akan merubah masukan menjadi keluaran. Contoh, sistem akuntansi. Sistem ini akan mengolah data transaksi menjadi laporan-laporan yang dibutuhkan oleh pihak manajemen.

8. Sasaran Sistem (Objective): Suatu sistem memiliki tujuan dan sasaran yang pasti. Jika suatu sistem tidak memiliki sasaran, maka operasi sistem tidak ada gunanya. Suatu sistem dikatakan berhasil bila mengenai sasaran atau tujuan yang telah direncanakan.

C. Informasi

Didalam pengolahan sistem pada akhirnya menghasilkan informasi, untuk itu pendefinisian informasi diperlukan untuk menunjang berhasilnya pengembang sistem yang akan dirancang. Definisi informasi menurut para ahli yaitu :

1. Jogiyanto Hartono "Informasi didefinisikan sebagai hasil dari pengolahan data dalam suatu bentuk yang lebih berguna dan lebih berarti bagi penerimanya yang menggambarkan suatu kejadian-kejadian (event) yang nyata (fact) yang digunakan untuk pengambilan keputusan"

2. Tata Sutabri "Informasi adalah sebuah istilah yang tidak tepat dalam pemakaiannya secara umum. Informasi dapat mengenai data mentah, data tersusun, kapasitas sebuah saluran komunikasi, dan lain sebagainya"

Informasi dalam suatu lingkungan sistem informasi memiliki beberapa ciri-ciri yaitu :

1. Benar atau salah, Ini dapat berhubungan dengan realitas atau tidak bila penerimaan informasi yang salah dipercayai mengakibatkan sama seperti benar.

2. Baru, informasi dapat sama sekali baru dan segar bagi penerimanya.

3. Tambahan, informasi dapat memperbaharui atau memberikan tambahan baru pada informasi yang telah ada.

4. Korektif, informasi dapat menjadi suatu korektif atas informasi yang salah.

5. Penegas, informasi dapat mempertegas informasi yang telah ada, ini berguna karena meningkatkan persepsi penerimanya atau kebenaran informasi tersebut.

Kualitas dari suatu informasi tergantung dari tiga hal yaitu informasi harus akurat, tepat pada waktunya dan relevan.

1. Akurat

Informasi harus bebas dari kesalahan-kesalahan. Akurat juga berarti informasi harus jelas mencerminkan maksudnya. Informasi harus akurat karena dari sumber informasi sampai penerima informasi kemungkinan banyak terjadi gangguan yang dapat mengubah atau merusak informasi tersebut.

2. Tepat pada waktunya

Informasi yang dating pada si penerima tifak boleh terlambat. Informasi yang sudah using tidak akan memiliki nilai lagi karena informasi merupakan landasan dalam pengambilan keputusan.

3. Relevan

Informasi tersebut mempunyai manfaat untuk pemakainya. Relevansi informasi untuk satu orang dengan yang lain berbeda.

Metode pengumpulan informasi yaitu pengamatan langsung, wawancara, perkiraan koresponden dan daftar pertanyaan. Kualitas informasi tergantung dari 3 hal, yaitu informasi harus :

1. Akurat, berarti informasi harus bebas dari kesalahankesalahan dan tidak bisa atau menyesatkan. Akurat juga berarti informasi harus jelas mencerminkan maksudnya.

2. Tepat pada waktunya, berarti informasi yang datang pada penerima tidak boleh terlimbat.

3. Relevan, berarti informasi tersebut mempunyai manfaat untuk pemakainya. Relevasi informasi untuk tiap-tiap orang satu dengan yang lainnya berbeda.

\section{Siklus Informasi}

Data yang diolah melalui suatu model menjadi informasi, penerima informasi kemudian menerima informasi tersebut, membuat suatu keputusan dan melakukan tindakan, sehingga menghasilkan suatu tindakan yang lain membuat sejumlah data kembali. Data tersebut diinput, diproses kembali lewat suatu model dan seterusnya hingga membentuk suatu siklus. Siklus ini oleh John Burch disebut dengan nama siklus informasi (information cycle).

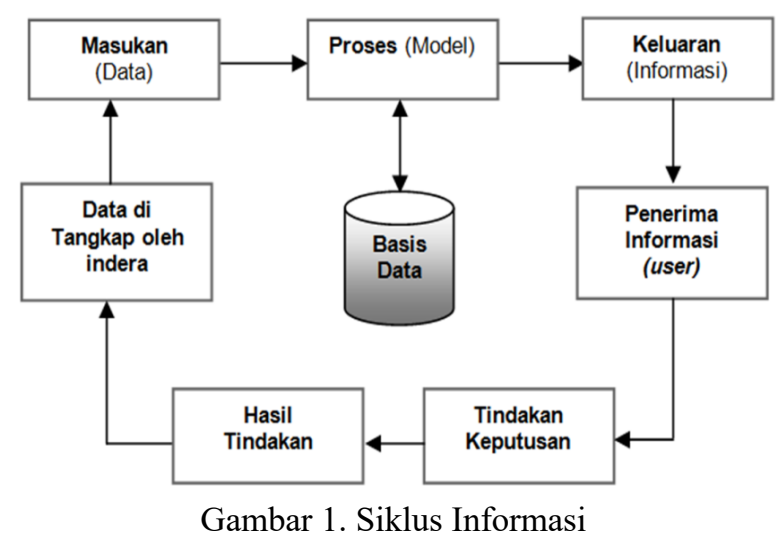

E. Nilai dan Kualitas Informasi

Nilai informasi ditentukan oleh 2 hal, yaitu manfaat dan biaya untuk mendapatkannya. Suatu informasi dikatakan bernilai bila manfaat lebih efektif dibandingkan dengan biaya mendapatkannya. Akan tetapi perlu diperhatikan bahwa informasi yang digunakan didalam suatu sistem informasi umumnya digunakan untuk beberapa kegunaan 
sehingga tidak memungkinkan dan sulit untuk menghubungkan suatu bagian informasi pada suatu masalah tertentu dengan biaya untuk memperolehnya karena sebagian informasi dinikmati tidak hanya oleh satu pihak didalam perusahaan.

Nilai informasi didasarkan atas 10 sifat :

1. Mudah diperoleh: Sifat ini menunjukkan mudahnya dan cepatnya informasi dapat diperoleh. Kecepatan memperoleh dapat diukur, misalnya 1 menit versus 24 jam. Akan tetapi, berapa nilainya bagi pemakai informasi sulit mengukurnya.

2. Luas dan lengkap: Sifat ini menunjukkan lengkapnya isi informasi. Hal ini tidak berarti hanya mengenai volumenya, tetapi juga mengenai keluaran informasinya. Sifat ini sangat kabur dank arena itu sulit mengukurnya.

3. Ketelitian: Sifat ini berhubungan dengan tingkat kebebasan dari kesalahan keluaran informasi. Dalam hubungannya dengan volume data yang besar biasanya terjadi dua jenis kesalahan, yakni kesalahan pencatatan dan kesalahan perhitungan.

4. Kecocokan: Sifat ini menunjukkan betapa baik keluaran informasi dalam hubungannya dengan permintaan para pemakai. Isi informasi harus ada hubungannya dengan masalah yang sedang dihadapi. Semua keluaran lainnya tidak berguna, tetapi mahal mempersiapkannya. Sifat ini sulit mengukurnya.

5. Ketepatan waktu: Sifat ini berhubungan dengan waktu yang dilalui yang lebih pendek dari pada siklus untuk mendapatkan informasi. Masukan, pengolahan, dan pelaporan keluaran kepada para pemakain biasanya tepat waktu.

6. Kejelasan: Sifat ini menunjukkan tingkat keluaran informasi yang bebas dari istilah-istilah yang tidak jelas. Membetulkan laporan dapat memakan biaya yang besar. Berapa biaya yang diperlukan untuk memperbaiki laporan tersebut?

7. Keluwesan: Sifat ini berhubungan dengan dapat disesuaikannya keluaran informasi tidak hanya dengan lebih dari satu keputusan, tetapi juga dengan lebih seorang pengambil keputusan. Sifat ini sulit diukut, tetapi dalam banyak hal dapat diberikan nilai yang dapat diukut.

8. Dapat dibuktikan: Sifat ini menunjukkan kemampuan beberapa pemakai informasi untuk menguji keluaran informasi dan sampai pada kesimpulan yang sama.

9. Tidak ada prasangka: Sifat ini berhubungan dengan tidak adanya keinginan untuk dipertimbangkan sebelumnya.

10. Dapat diukur: Sifat ini menunjukkan hakekat informasi yang dihasilkan dari sistem informasi formal. Meskipun kabar angina, desas-desus, dugaan-fugaan, klenik dan sebagainya sering dianggap informasi, hal-hal tersebut berapa di luar lingkup pembicaraan kita.
F. Sistem Informasi

Sistem informasi merupakan suatu sistem didalam suatu organisasi yang merupakan kombinasi dari orang-orang, fasilitas, teknologi, media, prosedur-prosedur dan pengendalian yang ditujukan untuk mendapatkan jalur komunikasi penting, memproses tipe transaksi rutin tertentu, memberi sinyal kepada manajemen dan yang lainnya terhadap kejadian-kejadian internal dan eksternal yang penting dan menyediakan suatu dasar informasi untuk pengambilan keputusan yang cerdik.

1. Komponen dan Jenis Sistem Informasi

Sistem informasi terdiri dari komponen-komponen yang disebut blok bangunan (building block), yang terdiri dari:

a. Blok Masukan (Input Block) Input mewakili data yang masuk ke dalam sistem informasi. Input di sini termasuk metode dan media untuk menangkap data yang akan dimasukkan, yang data berupa dokumen-dokumen dasar.

b. Blok Model (Model Block) Blok ini terdiri dari kombinasi prosedur, logika dan model mematik yang akan memanipulasi data input dan data yang tersimpan di basis data dengan cara yang sudah tertentu untuk menghasilkan keluaran yang diinginkan.

c. Blok Keluaran (Output Block) Produk dari sistem informasi ini adalah keluaran yang merupakan informasi yang berkualitas dan dokumentasi yang berguna untuk semua tingkatan manajemen serta pemakain sistem.

d. Blok Teknologi (Technology Block) Teknologi merupakan "tool box" dalam sistem informasi. Teknologi digunakan untuk menerima input, menjalankan model, menyimpan dan mengakses data, menghasilkan dan mengirimkan keluaran, dan membantu pengendalian dari sistem secara keseluruhan.

e. Blok Basis Data (Database Block) Basis data (database) merupakan kumpulan data yang saling berkaitan dengan dan berhubungan satu dengan yang lain, tersimpan di perangkat keras komputer dan menggunakan perangkat lunak untuk memanipulasinya.

f. Blok Kendali (Control Block) Banyak hal yang dapat merusak sistem informasi, seperti bencana alam, api, temperature, air, debu, kecurangankecurangan, kegagalan-kegagalan sistem itu sendiri, ketidak efisienan, sabotase, dan lain sebagainya. Beberapa pengendalian perlu dirancang dan diterapkan untuk meyakinkan bahwa hal-hal yang dapat merusak sistem dapat dicegah ataupun bila terlanjur terjadi kesalahankesalahan dapat langsung cepat diatasi. 
2. Perencanaan Sistem Informasi

Untuk memahami bagaimana merencanakan sistem informasi yang tepat dan sesuai dengan organisasi masingmasing, berikut dibahas bagaimana informasi itu mengalir dari satu tempat ke tempat lain, bagaimana merencanakan sistem informasi secara keseluruhan, serta bagaimana merencanakan sistem informasi per bagian. Perlu diingat, perubahan sistem, baik besar maupun kecil, selalu akan melalui tingkatan-tingkatan sebagai berikut :

Tingkat I : Ide, mengetahui perlu adanya perubahan

Tingkat II : Design, merancang cara pemecahannya

Tingkat III : Pelaksanaan, menerepkan design ke dalam sistem

Tingkat IV : Kontrol, memeriksa tingkat pelaksanaan dijalankan sesuai dengan design.

Tingkat V : Evaluasi, memeriksa apakah perubahan yang terjadi sesuai dengan tujuan semula.

Tingkat VI : Tindak lanjut, melaksanakan perubahan sesuai dengan hasil evaluasi yang ada

Oleh karena itu, bahan perencanaan sistem informasi yang akan dibahas berkisar pada keempat tingkatan ini.

IDE ---> DESIGN ---> PELAKSANAAN ----> EVALUASI

3. Pengendalian Sistem Informasi

Pengelola sistem informasi merupakan perlu memahami dan memiliki keterampilan manajerial dalam melaksanakan kegiatan pengendalian sistem informasi, yakni :

a. Kemampuan mengendalikan kegiatan perencanaan informasi.

b. Kemampuan mengendalikan proses transformasi informasi.

c. Kemampuan mengendalikan organisasi pelaksana sistem informasi.

d. Kemampuan melaksanakan kegiatan koordinasi. Dengan kemampuan-kemampuan itu, maka terjaminlah kelancaran pelaksanaan pengelolaan sistem informasi guna mendukung keberhasilan program organisasi.

4. Penilaian Sistem Informasi

Berdasalkan hasil penilaian dapat dibuat keputusan yang tepat yang objektif tentang berbagai kegiatan pengelolaan sistem informasi tentang :

a. Derajat keakuratan informasi yang diperoleh berdasarkan kebutuhan lapangan secara nyata.

b. Perencanaan sistem informasi yang bermutu, artinya memnuhi persyaratan yang ditetapkan bagi suatu rencana informasi yang baik.

c. Pelaksanaan kegiatan transformasi data dan informasi berdasarkan prosedur yang tepat dan benar.

d. Jenis dan mutu produk informasi yang dihasilkan oleh sistem informasi.

\section{G. Stok Barang}

Stok barang merupakan barang-barang yang disimpan untuk digunakan atau dijual pada masa atau periode yang akan datang. Persediaan ini terdiri dari persediaan bahan baku, persediaan barang setengah jadi dan persediaan barang jadi. Persediaan barang jadi dan barang setengah jadi disimpan sebelum digunakan atau dimasukkan ke dalam proses produksi, sedangkan persediaan jadi atau barang dagangan disimpan sebelum dijual atau dipasarkan. Dengan demikian perusahaan yang melakukan kegiatan usaha pada umumnya memiliki persediaan.

\section{H. Metode Double Exponential Smoothing}

Exponential Smoothing adalah perataan eksponensial dari data deret waktu memberikan bobot yang menurun secara eksponensial untuk observasi terbaru hingga tertua. Dengan kata lain, semakin tua data, semakin kecil prioritas (berat) data diberikan. Data yang lebih baru dipandang lebih relevan dan diberi bobot lebih. Parameter pemulusan (Exponential Smoothing) biasanya dilambangkan dengan a, untuk menentukan bobot untuk observasi. Metode Double Exponential Smoothing lebih andal untuk menganalisa data yang menunjukkan trend.

\section{Konsep Permodelan Sistem}

Bagan adalah alat bantu yang berbentuk grafik yang sifatnya umum, yaitu dapat digunakan pada semua metodologi yang ada. Pada penyusunan laporan ini penulis menggunakan alat-alat bantu sebagai berikut :

1. Bagan Alir (Flowchart)

Flowchart adalah bagan alir yang menunjukkan dan menjelaskan sistem informasi yang terdapat didalam program atau prosedur secara tepat dan logis berdasarkan logika.

2. Diagram Konteks

Diagram konteks merupakan gambaran kasar aliran informasi dan data yang akan dilakukan oleh sistem database yang akan dirancang, diagram ini hanya menjelaskan secara umum gambaran aliran konteks dari rancangan sistem yang akan dibuat.

3. Data Flow Diagram (DFD)

DFD (Data Flow Diagram) suatu network yang menggambarkan suatu sistem format atau komputerisasi, manualisasi atau gabungan dari keduanya, yang penggambarannya disusun dalam bentuk kumpulan komponen sistem yang saling berhubungan sesuai dengan aturan mainnya. Keuntungan DFD adalah memungkinkan untuk menggambarkan sistem dari level yang paling tinggi kemudian menguraikan menjadi level yang lebih rendah. Kekurangan DFD adalah tidak menunjukkan proses pengulangan, proses keputusan dan proses perhitungan. Komponen-komponen dalam Data Flow Diagram yaitu sebagai berikut:

1. Proses 
Aktivitas atau fungsi yang dilakukan untuk alasan bisnis yang spesifik biasa berupa manual maupun terkomputerisasi. Proses menggambarkan bagian dari sistem yang transformalkan input menjadi output. Proses juga diberi nama untuk menjelaskan proses atau kegiatan apa yang sedang atau akan dilaksanakan.

\section{Data Flow}

Satu data tunggal atau kumpulan logis suatu data, selalu diawali atau berakhir pada suatu proses, yang menghubungkan data store dengan suatu proses.

3. Simpanan Data (Data Store)

Kumpulan data yang disimpan dengan cara tertentu. Data yang mengalir disimpan dalam data store. Aliran data di update atau ditambahkan ke data store. Data store ini biasanya berkaitan dengan penyimpanan, seperti file atau database.

J. Konsep Basis Data

Basis data merupakan kumpulan terorganisasi dari datadata yang berhubungan sehingga mudah disimpan, dimanipulasi, serta di panggil oleh pengguna. Suatu basis data dibuat dan digunakan untuk mengatasi masalah masalah yang ada pada saat penggunaan data.

Masalah - masalah tersebut antara lain :

1. Redudansi dan konsistensi data.

2. Kesulitan pengaksesan data.

3. Isolasi data untuk standarisasi.

4. Banyak pemakai (multiple user).

5. Masalah keamanan (security).

6. Masalah integrasi (integration).

7. Masalah kebebasan data (independence).

Pelaksanaan penggunaan database memerlukan suatu sistem yang dapat mengatur dan mengelola data, program yang disebut Database Management System (DBMS), yaitu pengelolaan sekumpulan data yang saling berkaitan antara data yang satu dengan data yang lainnya.

a. Desain Basis Data Sistem: Basis data (database) adalah suatu pengorganisasian sekumpulan data yang saling terkait sehingga memudahkan aktivitas untuk memperoleh informasi. Merancang basis data merupakan hal sangat penting dalam perancangan suatu sistem. Kesulitan utama dalam merancang suatu basis data adalah bagaimana cara merancang suatu basis data yang dapat memuaskan keperluan saat ini dan masa yang akan datang. Elemen - elemen data dalam suatu basis data harus dapat dipergunakan untuk pembuatan keluaran (output), sesuai dengan yang diinginkan. Untuk menghasilkan keluaran yang baik, juga diperlukan masukan (input) yang baik. Hasil pemasukan data ini akan disimpan atau direkam dalam basis data.

b. Model ERD (Entity Relationship Diagram)

ERD (Entity Relationship Diagram) adalah suatu model jaringan/penggambaran himpunan entitas dan himpunan relasi yang dilengkapi dengan atribut-atribut yang mempresentasikan seluruh fakta dari dunia nyata yang ditinjau kemudian disimpan didalam sistem secara abstrak.

Notasi-notasi simbolik di dalam Diagram E-R yang dapat kita gunakan adalah:

1) Persegi panjang, menyatakan himpunan entitas.

2) Lingkaran/elips, menyatakan atribut (atribut yang berfungsi sebagai key digaris bawahi).

3) Belah ketupat, menyatakan himpunan relasi.

4) Garis, sebagai penghubung antara himpunan relasi dengan himpunan entitas dan himpunan entitas dengan atributnya.

5) Kardinalitas relasi dapat dinyatakan dengan banyaknya garis cabang atau dengan pemakaian angka (1 dan 1 untuk relasi satu ke satu, 1 dan $\mathrm{N}$ untuk relasi satu ke banyak atau $\mathrm{N}$ dan $\mathrm{N}$ untuk relasi banyak ke banyak).

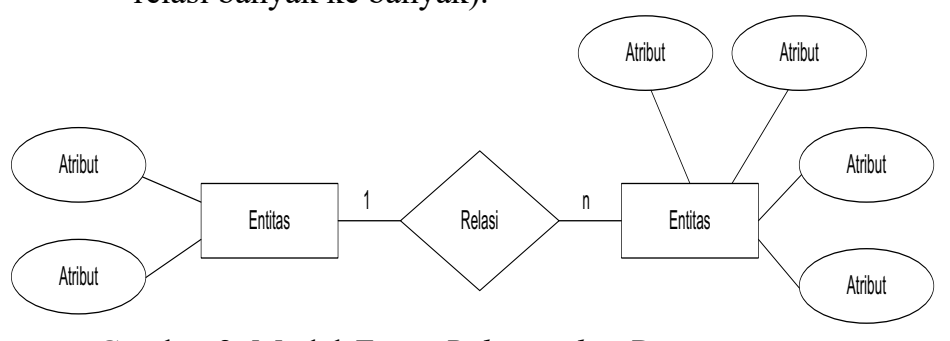

Gambar 2. Model Entity Relationship Diagram

K. Teknik Normalisasi

Normalisasi merupakan proses pengelompokan data elemen menjadi table-tabel yang menunjukkan entity dan relasinya. Sebelum mengenal lebih jauh, ada beberapa konsep yang perlu diketahui yaitu :

1. Attribute Key

Setiap file selalu terdapat kunci dari file atau satu set field yang dapat mewakili record.

2. Candidate Key

Candidate key adalah satu atribut atau satu set minimal atribut yang mengidentifikasi secara unik suatu kejadian spesifik dari entiti dan Candidate key tidak boleh berisi atribut dari tabel yang lain.

\section{Primary Key}

Primary key adalah satu atribut atau satu set minimal atribut yang tidak hanya mengidentifikasi secara unik suatu kejadian spesifik, tetapi dapat juga mewakili setiap kejadian dari entiti.

4. Alternative KeySetiap atribut dari candidate keyyang tidak terpilih menjadi primary key, maka atribut atribut tersebut dinamakan alternative key.

5. Foreign Key

Foreign key merupakan sembarang atribut yang menunjuk kepada primary key pada tabel yang lain. Foreign key akan terjadi pada suatu relasi yang memiliki kardinalitas one to many (satu ke banyak) atau many to many (banyak ke banyak). Foreign key biasanya selalu diletakkan pada tabel atau relasi mengarah ke banyak.

L. Teori Bahasa Basis Data (SQL) 
SQL adalah suatu bahasa komputer yang mengikuti standard ANSI (American National Standard Institute), yaitu sebuah bahasa standard yang digunakan untuk mengakses dan melakukan manipulasi suatu sistem database. Statement dalam SQL dapat digunakan untuk mengakses data atau meng-update data pada suatu database. SQL utamanya berfungsi dalam suatu relational database seperti misalnya Oracle, SQL Server, DB2, Informix, Sybase, MS Access, MySQL, Firebird dan masih banyak lagi yang lainnya.

Dengan adanya berbagai perusahaan/vendor yang membuat berbagai produk SQL maka efeknya adalah timbul berbagai macam perbedaan dalam bahasa SQL yangdikembanglan oleh tiap-tiap perusahaan tersebut. Contohnya saja, bahasa SQL yangdimiliki oleh Microsoft (yang bernama T-SQL) akan berbeda dengan bahasa SQL yang dikembangkan oleh Oracle (yang bernama PL/SQL). Namun demikian semua vendor diwajibkan untuk mendukung bahasa standard yang ditentukan oleh ANSI, misalnya semua pengembang bahasa SQL wajib dalam mengimplementasikan kata kunci atau statemen standard SQL seperti SELECT, UPDATE, DELETE, INSERT, WHERE dan lain sebagainya. Perbedaan bahasa SQL yang dikembangkan oleh setiap vendor itu dinamakan extension atau juga disebut dengan dialek.

\section{ANALISIS SISTEM}

A. Analisis Sistem yang Sedang Berjalan

Prosedur merupakan tahapan-tahapan, langkah-langkah yang dilalui untuk mencapai suatu hasil yang diinginkan. Setiap langkah dalam prosedur tersebut harus dianalisa sedemikian rupa, sehingga proses bisnis didalamnya menjadi lengkap dan rinci, yang nantinya pada tahap perancangan sistem akan menjadi lebih mudah untuk dilakukan.

1. Prosedur Penerimaan Barang dari Supplier yang Sedang Berjalan

a. Supplier menerima purchase order dari Purchasing.

b. Supplier memproses pesanan dari Purchasing, dan terbit nota yang sudah ditanda tangan dan di cap.

c. Supplier mengirim barang berdasarkan orderan dari Purchasing.

d. Oleh pihak gudang mengecek formulir purchase order dengan nota dan barang yang diterima, jika tidak sesuai maka barang akan dikembalikan ke Supplier untuk diproses kembali, jika barang sesuai maka pihak gudang akan menandatangani nota tersebut dan serahkan ke supplier dan diserahkan juga ke Administrasi untuk arsip.

Untuk lebih jelasnya prosedur penerimaan barang dari Supplier dapat dilihat pada gambar flowmap berikut ini :

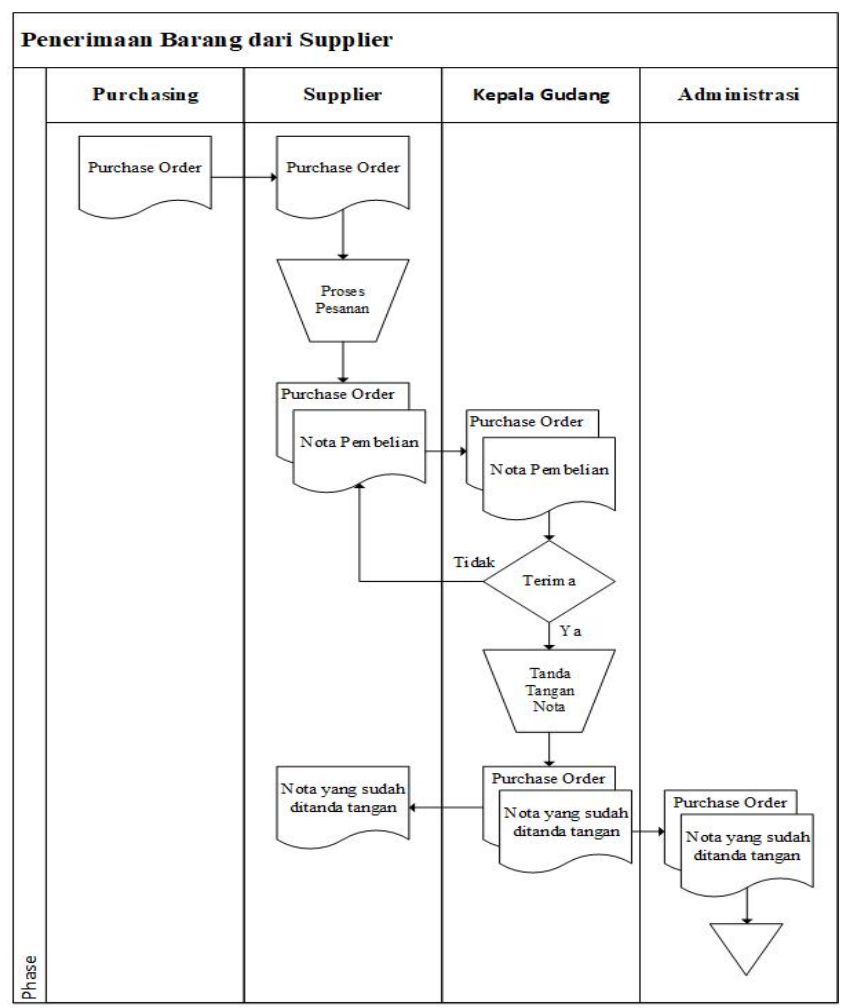

Gambar 3. Flowmap Penerimaan Barang dari Supplier

2. Prosedur Pengeluaran Barang ke Customer yang Sedang Berjalan

a. Sales memberikan daftar orderan dari pelanggan kepada bagian gudang.

b. Begian gudang akan mengecek ketersediaan barang yang diminta, jika barang tidak ada maka daftar orderan dikembalikan ke Sales, jika barang ada maka bagian gudang akan membuat data barang yang serahkan ke Sales.

c. Sales terbit nota sesuai dengan data barang yang sudah disiapkan oleh pihak gudang dan mengirim barang tersebut ke pelanggan.

d. Pelanggan mengecek barang yang dikirim berdasarkan nota yang sudah diterbit oleh Sales, jika tidak sesuai maka dari Sales akan terbit ulang nota tersebut, jika sesuai maka pelanggan akan menandatangani nota tersebut sebagai bukti barang terima dan dikembalikan kepada Sales.

e. Sales serahkan nota yang sudah ditandatangani oleh pelanggan kepada bagian administrasi untuk arsip.

Untuk lebih jelasnya prosedur pengeluaran barang ke pelanggan dapat dilihat pada gambar flowmap berikut ini : 


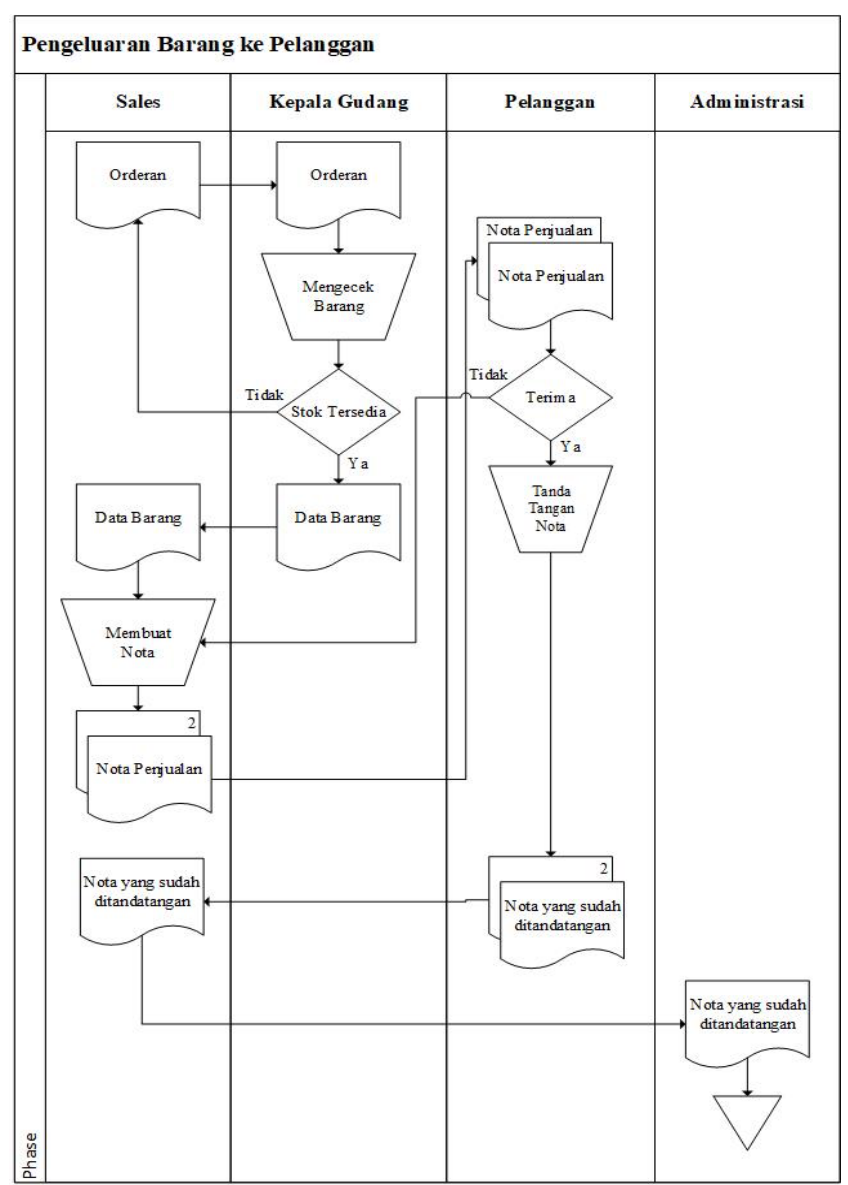

Gambar 4. Flowmap Pengeluaran Barang ke Pelanggan

3. Prosedur Pengiriman Barang ke Outlet yang Sedang Berjalan

a. Logistik memberikan daftar request stok kepada bagian gudang.

b. Bagian gudang akan mengecek ketersediaan barang yang diminta, jika barang tidak ada maka daftar tersebut akan dicatat kembali untuk diserahkan ke Purchasing untuk order barang tersebut dengan pihak Supplier, jika barang ada maka bagian gudang akan membuat surat jalan dan serahkan kepada pihak logistik.

c. Outlet mengecek barang yang dikirim berdasarkan surat jalan yang sudah dibuat oleh bagian gudang, jika tidak sesuai maka pihak logistik membuat surat jalan ulang, jika sesuai maka outlet akan menandatangani surat jalan tersebut sebagai bukti terima barang dan dikembalikan kepada pihak logistik.

d. Logistik serahkan surat jalan yang sudah ditandatangani outlet kepada administrasi sebagai arsipan.

Untuk lebih jelasnya prosedur pengiriman barang ke outlet dapat dilihat pada gambar flowmap berikut ini

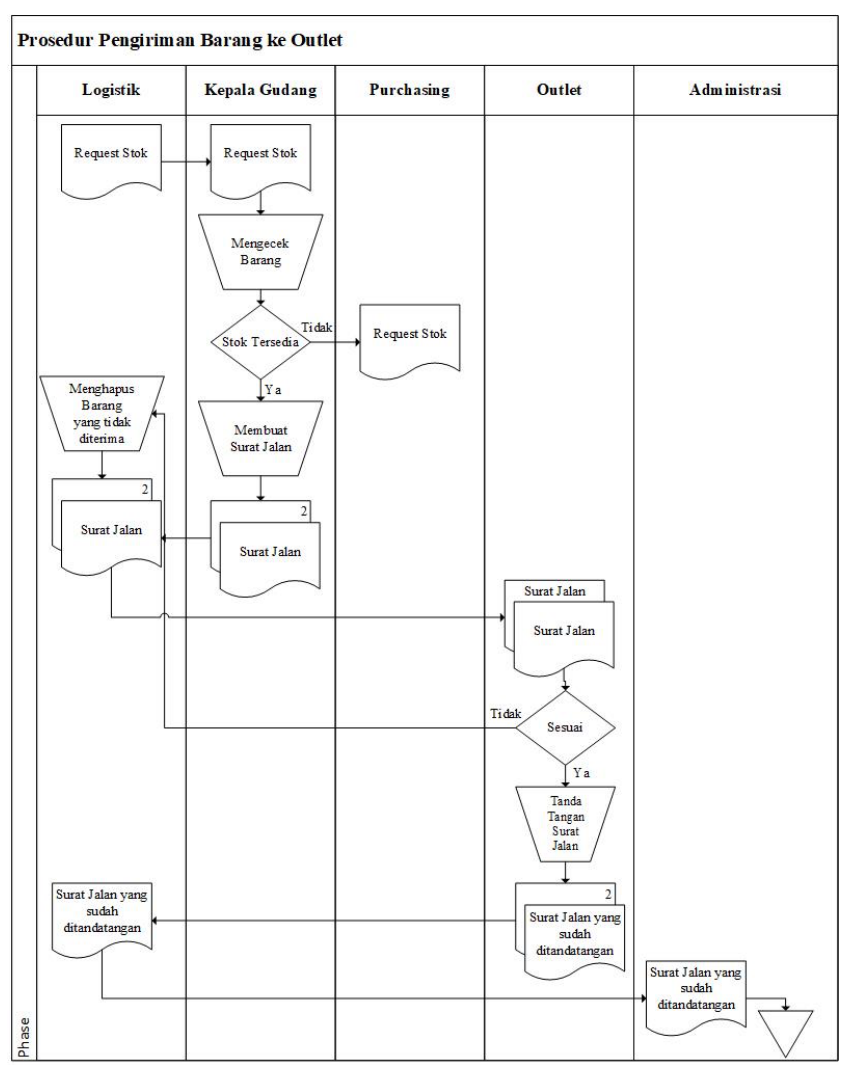

Gambar 5. Flowmap Pengiriman Barang ke Outlet

B. Analisis Kelemahan Sistem

Analisis sistem merupakan sebuah kegiatan yang dilakukan dengan tujuan untuk memahami cara kerja dari sistem pada suatu instansi/objek yang diteliti. Salah satu dari tujuan memahami cara kerja dari sistem tersebut adalah untuk mencari kelemahan-kelemahan yang ada pada sistem lama dan memperbaikinya untuk hasil kinerja (output) sistem yang lebih optimal.

Berdasarkan penelitian yang telah dilakukan, maka ditemukan beberapa kelemahan-kelemahan yang ada pada sistem yang sedang berjalan di PT.Dima Habadi :

1. Pencarian data vendor atau pelanggan masih secara manual.

2. Proses perhitungan pada nota dan surat jalan masih secara manual sehingga membutuhkan waktu yang lama.

3. Proses data masih menggunaka excel akan lambatnya penyajian informasi dalam bentuk laporan

Untuk mengatasi masalah-masalah di atas maka diperlukan sebuah sistem yang mampu memperbaiki cara kerja dari sistem pengolahan data stok tersebut, terutama dalam hal pembuatan laporan, sebagai output bagi tersediannya suatu penyajian informasi yang dibutuhkan.

C. Analisis Metode

1. Metode Double Exponential Smoothing

Metode ini merupakan model linier yang dikemukakan oleh brown. Didalam metode Double Exponential 
Smoothing dilakukan proses smoothing dua kali, sebagai berikut :

$$
\begin{aligned}
& S_{t}^{\prime \prime}=\alpha \cdot X_{t}+(1-\alpha) S_{t-1}^{\prime} \\
& S_{t}^{\prime \prime}=\alpha \cdot S_{t}^{\prime}+(1-\alpha) S_{t-1}^{\prime \prime} \\
& a_{t}=2 S_{t}^{\prime}-S_{t}^{\prime \prime} \\
& b_{t}=\frac{a}{1-a}\left(S_{t}^{\prime}-S_{t}^{\prime \prime}\right) \\
& S_{t+m}=a_{t}+b_{t} m
\end{aligned}
$$

Keterangan :

$S_{t+m}=$ Nilai ramalan untuk $m$ periode ke depan $m=$ Jarak periode yang akan diramalkan

$X_{t}=$ Nilai actual periode ke-t

$S^{\prime}{ }_{t}=$ Nilai Smoothing periode ke-t

$a=$ Konstanta pemulusan

Contoh bila data terdiri dari 11 bulan, maka a dapat diperoleh dengan menggunakan perhitungan sebagai berikut:

$\mathrm{a}=2 /(\mathrm{n}+1)$

$\mathrm{a}=2 /(11+1)$

$\mathrm{a}=2 / 12$

$\mathrm{a}=0,16667$

jadi nilai konstanta yang dapat kita gunakan adalah 0,2

2. Contoh Kasus

PT. Dima Habadi sudah terdapat data produk barang selama 11 bulan sebelumnya dan akan menghitung peramalan jumlah pembelian produk tersebut untuk bulan berikutnya (bulan ke-12).

Tabel 1. Tabel Data Barang Keluar Tahun 2018

\begin{tabular}{|c|c|c|}
\hline BULAN & t & $\begin{array}{c}\text { Stok Keluar Y(t) } \\
\text { (unit) }\end{array}$ \\
\hline JAN & 1 & 3197 \\
\hline FEB & 2 & 3348 \\
\hline MAR & 3 & 3476 \\
\hline APR & 4 & 3643 \\
\hline MAY & 5 & 3426 \\
\hline JUN & 6 & 3714 \\
\hline JUL & 7 & 3135 \\
\hline AUG & 8 & 3092 \\
\hline SEP & 9 & 3851 \\
\hline OCT & 10 & 3566 \\
\hline NOV & 11 & 3493 \\
\hline
\end{tabular}

Akan diperhitungkan untuk periode kedepan dengan $a=0,5$

$$
\begin{aligned}
& S_{t}^{\prime}=a \cdot X_{t}+(1-a) S_{t-1}^{\prime} \\
& S_{1}^{\prime}=3197 \\
& S_{2}^{\prime}=(0,5) 3197+(1-0,5) 3348=3272,50 \\
& S_{3}^{\prime}=(0,5) 3272,50+(1-0,5) 3476=3374,25
\end{aligned}
$$

$$
\begin{aligned}
& S^{\prime}{ }_{4}=(0,5) 3374,25+(1-0,5) 3643=3508,63 \\
& S^{\prime}{ }_{5}=(0,5) 3508,63+(1-0,5) 3426=3467,31 \\
& S^{\prime}{ }_{6}=(0,5) 3467,31+(1-0,5) 3714=3590,66 \\
& S^{\prime}{ }_{7}=(0,5) 3590,66+(1-0,5) 3135=3362,83 \\
& S_{8}^{\prime}=(0,5) 3362,83+(1-0,5) 3092=3227,41 \\
& S_{9}^{\prime}=(0,5) 3227,41+(1-0,5) 3851=3539,21 \\
& S^{\prime}{ }_{10}=(0,5) 3539,21+(1-0,5) 3566=3552,60 \\
& S^{\prime}{ }_{11}=(0,5) 3522,60+(1-0,5) 3493=3522,80 \\
& S_{t}^{\prime \prime}=a \cdot S_{t}^{\prime}+(1-a) S_{t-1}^{\prime \prime} \\
& S^{\prime \prime}{ }_{1}=3197 \\
& S_{2}^{\prime \prime}=(0,5) 3272,50+(1-0,5) 3197=3234,75 \\
& S^{\prime \prime}{ }_{3}=(0,5) 3374,25+(1-0,5) 3234,75=3304,50 \\
& S^{\prime \prime}{ }_{4}=(0,5) 3508,63+(1-0,5) 3304,50=3406,56 \\
& S^{\prime \prime}{ }_{5}=(0,5) 3467,31+(1-0,5) 3406,56=3436,94 \\
& S^{\prime \prime}{ }_{6}=(0,5) 3590,66+(1-0,5) 3436,94=3513,80 \\
& S^{\prime \prime}{ }_{7}=(0,5) 3362,83+(1-0,5) 3513,80=3438,31 \\
& S^{\prime \prime}{ }_{8}=(0,5) 3227,41+(1-0,5) 3438,31=3332,86 \\
& S^{\prime \prime}{ }_{9}=(0,5) 3539,21+(1-0,5) 3332,86=3436,04 \\
& S^{\prime \prime}{ }_{10}=(0,5) 3552,60+(1-0,5) 3436,04=3494,32 \\
& S^{\prime \prime}{ }_{11}=(0,5) 3522,80+(1-0,5) 3494,32=3508,56 \\
& a_{t}=2 S^{\prime}{ }_{t}-S^{\prime \prime}{ }_{t} \\
& a_{1}=0 \\
& a_{2}=2(3272,50)-3234,75=3310,25 \\
& a_{3}=2(3374,25)-3304,50=3444 \\
& a_{4}=2(3508,63)-3406,56=3610,69 \\
& a_{5}=2(3467,31)-3436,94=3497,69 \\
& a_{6}=2(3590,66)-3513,80=3667,52 \\
& a_{7}=2(3362,83)-3438,31=3287,34 \\
& a_{8}=2(3227,41)-3332,86=3121,96 \\
& a_{9}=2(3539,21)-3436,04=3642,38 \\
& a_{10}=2(3552,60)-3494,32=3610,89 \\
& a_{11}=2(3522,80)-3508,56=3537,04 \\
& b_{t}=\frac{a}{1-a}\left(S_{t}^{\prime}-S_{t}^{\prime \prime}\right) \\
& b_{1}=0 \\
& b_{2}=\frac{0,5}{0,5}(3272,50-3234,75)=37,75 \\
& b_{3}=\frac{0,2}{0,8}(3374,25-3304,50)=69,75 \\
& b_{4}=\frac{0,2}{0,8}(3508,63-3406,56)=102,06 \\
& b_{5}=\frac{0,2}{0,8}(3467,31-3436,94)=30,38 \\
& b_{6}=\frac{0,2}{0,8}(3590,66-3513,80)=76,86 \\
& b_{7}=\frac{0,2}{0,8}(3362,83-3438,31)=-75,48 \\
& b_{8}=\frac{0,2}{0,8}(3227,41-3332,86)=-105,45 \\
& b_{9}=\frac{0,2}{0,8}(3539,21-3436,04)=103,17 \\
& b_{10}=\frac{0,2}{0,8}(3552,60-3494,32)=58,28 \\
& b_{11}=\frac{0,2}{0,8}(3522,80-3508,56)=14,24 \\
& S_{t+m}=a_{t}+b_{t} m \mathrm{~m} \\
& \text { Jadi, } F_{12+m}=3537,04+14,24
\end{aligned}
$$


Dengan demikian hasil peramalan untuk bulan berikutnya adalah : 3551,28

D. Analisis Kebutuhan Sistem

Untuk mendukung sistem informasi perhitungan stok pada PT.Dima Habadi, dibutuhkan beberapa komponenkomponen dasar yang harus terpenuhi, diantaranya :

1. Analisis Kebutuhan Perangkat Lunak

2. Analisis Kebutuhan Perangkat Keras

3. Analisis Kebutuhan Informasi

4. Analisis Kebutuhan Pengguna

\section{PERANCANGAN SISTEM}

A. Flowchart Metode Double Exponential Smoothing

Dibawah ini adalah gambar flowchart metode Double Exponential Smoothing.

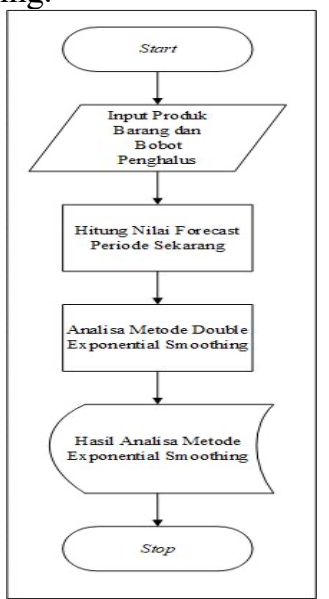

Gambar 6. Flowmap Metode Double Exponential Smoothing

B. Perancangan Proses

Perancangan proses merupakan desain dari hasil analisa yang telah dilakukan untuk memenuhi permintaanpermintaan sistem dan gambaran-gambaran perancangan proses akan dibuat dalam belum flowmap usulan, diagram konteks dan data flow diagram.

1. Prosedur Usulan Penerimaan Barang dari Supplier

a. Administrasi memproses laporan forecast dari data stok.

b. Laporan Forecast diserahkan ke Purchasing.

c. Supplier menerima purchase order dari Purchasing.

d. Supplier memproses pesanan dari Purchasing, dan terbit nota yang sudah ditanda tangan dan di cap.

e. Supplier mengirim barang berdasarkan orderan dari Purchasing.

f. Oleh pihak gudang mengecek formulir purchase order dengan nota dan barang yang diterima, jika tidak sesuai maka barang akan dikembalikan ke Supplier untuk diproses kembali, jika barang sesuai maka pihak gudang akan menandatangani nota tersebut dan serahkan ke supplier dan diserahkan juga ke Administrasi.
1. Administrasi menginput nota pembelian ke dalam database dan diarsip.

Untuk lebih jelasnya prosedur usulan penerimaan barang dari Supplier dapat dilihat pada gambar flowmap berikut ini :

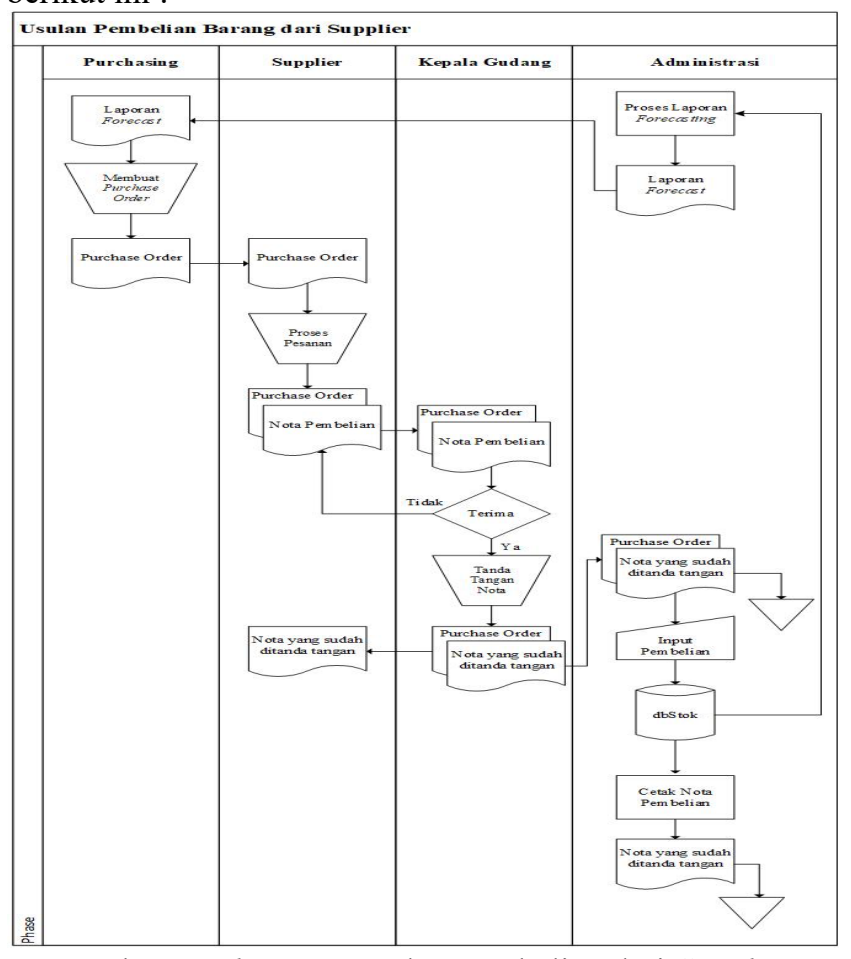

Gambar 7. Flowmap Usulan Pembelian dari Supplier

g. Prosedur Usulan Pengeluaran Barang ke Customer

1) Sales memberikan daftar orderan dari pelanggan kepada bagian gudang.

2) Bagian gudang akan mengecek ketersediaan barang yang diminta, jika barang tidak ada maka daftar orderan dikembalikan ke Sales, jika barang ada maka bagian gudang akan membuat data barang yang serahkan ke Sales.

3) Sales terbit nota sesuai dengan data barang yang sudah disiapkan oleh pihak gudang dan mengirim barang tersebut ke pelanggan.

4) Pelanggan mengecek barang yang dikirim berdasarkan nota yang sudah diterbit oleh Sales, jika tidak sesuai maka dari Sales akan terbit ulang nota tersebut, jika sesuai maka pelanggan akan menandatangani nota tersebut sebagai bukti barang terima dan dikembalikan kepada Sales.

5) Sales serahkan nota yang sudah ditandatangani oleh pelanggan kepada bagian administrasi untuk diinput ke dalam database.

6) Administrasi mencetak nota tersebut kemudian di arsip.

Untuk lebih jelasnya prosedur usulan pengeluaran barang ke Customer dapat dilihat pada gambar flowmap berikut ini : 


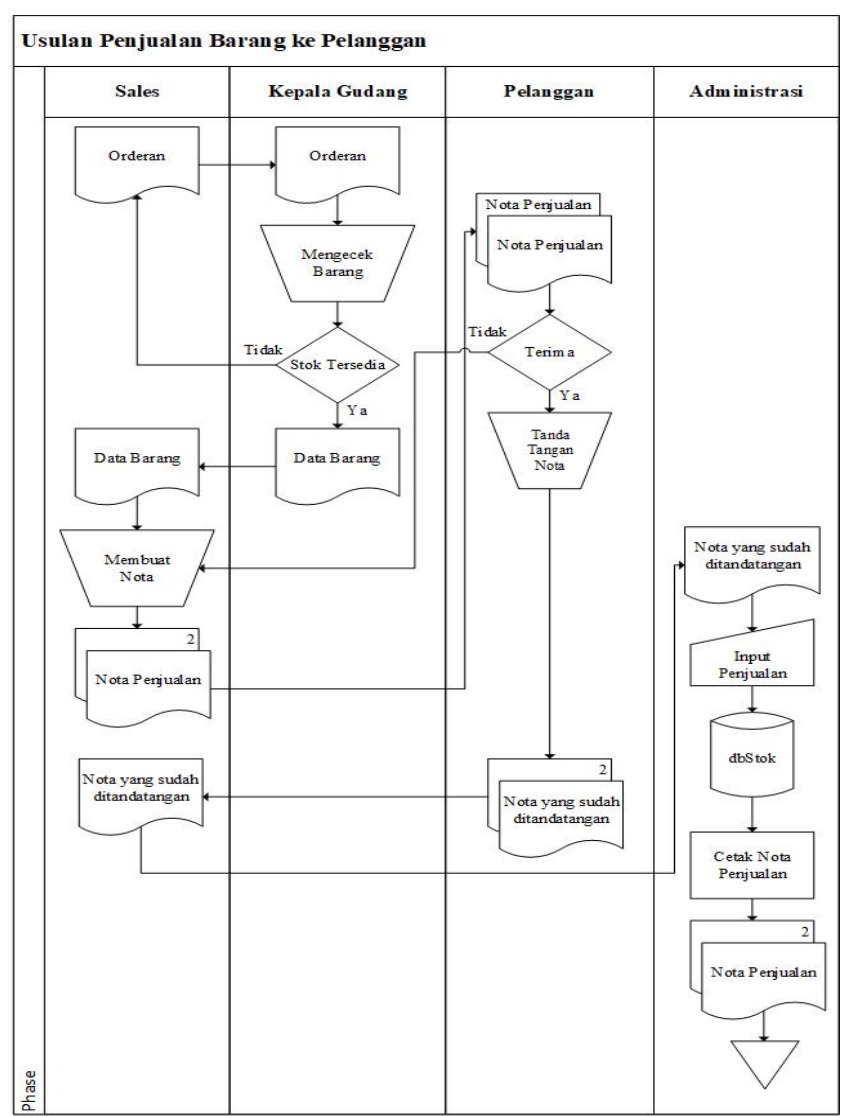

Gambar 8. Flowmap Usulan Penjualan Barang ke Customer

h. Prosedur Usulan Pengiriman Barang ke Outlet

1) Logistik memberikan daftar request stok kepada bagian gudang.

2) Bagian gudang akan mengecek ketersediaan barang yang diminta, jika barang tidak ada maka daftar tersebut akan dicatat kembali untuk diserahkan ke Purchasing untuk order barang tersebut dengan pihak Supplier, jika barang ada maka bagian gudang akan membuat surat jalan dan serahkan kepada pihak logistik.

3) Outlet mengecek barang yang dikirim berdasarkan surat jalan yang sudah dibuat oleh bagian gudang, jika tidak sesuai maka pihak logistik membuat surat jalan ulang, jika sesuai maka outlet akan menandatangani surat jalan tersebut sebagai bukti terima barang dan dikembalikan kepada pihak logistik.

4) Logistik serahkan surat jalan yang sudah ditandatangani outlet kepada administrasi untuk diinput ke dalam database.

5) Administrasi mencetak laporan barang pindah gudang tersebut kemudian di arsip.

Untuk lebih jelasnya prosedur usulan pengiriman barang ke outlet dapat dilihat pada gambar flowmap berikut ini :

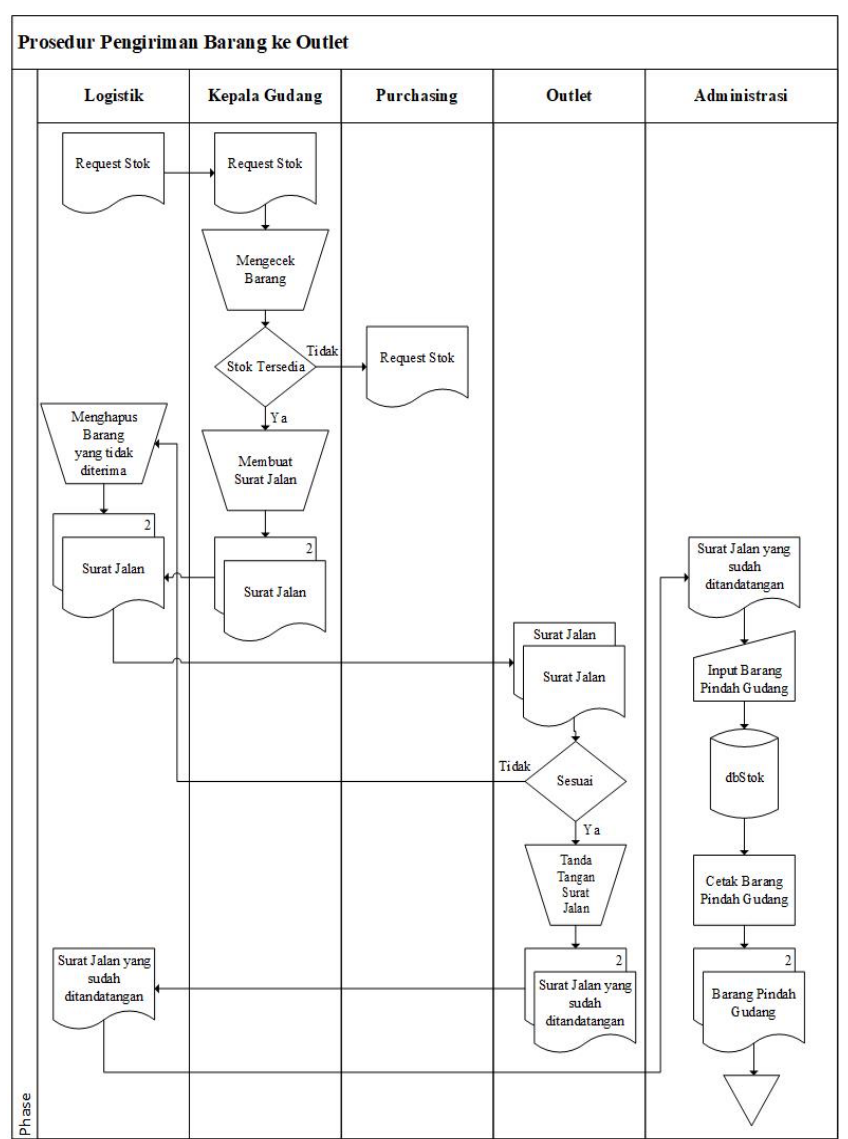

Gambar 9. Flowmap Usulan Pengiriman Barang ke Outlet

i. Diagram Konteks

Diagram konteks adalah diagram yang menggambarkan hubungan antara entitas eksternal dengan sistem. Dimana data yang diinputkan oleh bagian entitas eksternal akan diproses didalam sistem dan akan menghasilkan laporan yang diinginkan oleh entitas eksternal tersebut.

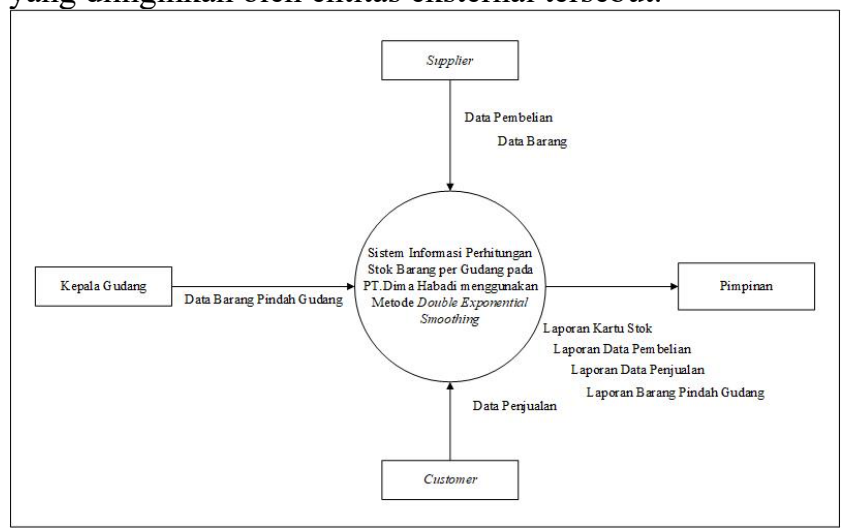

Gambar 10. Diagram Konteks

\section{j. Data Flow Diagram}

Data Flow Diagaram (DFD) adalah diagram yang digunakan untuk menggambarkan suatu sistem yang sudah jadi atau sistem yang baru dirancang yang akan dikembangkan secara logika, tanpa mempertimbangkan 
lingkungan fisik kemana data tersebut disimpan. Disamping itu Data Flow Diagram (DFD) juga dapat menggambarkan arus data yang terstruktur dan jelas dari mulai pengisian data sampai dengan keluarannya.

Arus data pada Data Flow Diagaram (DFD) ini dapat berupa masukan untuk sistem atau keluaran dari sistem, sehingga akan menghasilkan sebuah keluaran yang akan disampaikan pada pengguna atau penerima sistem.

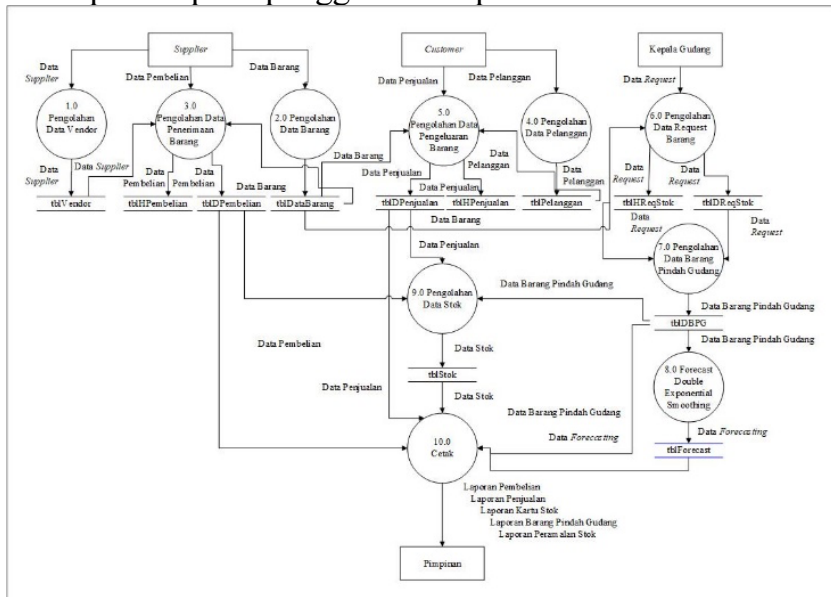

Gambar 11. Data Flow Diagram

Dari DFD Level 0 terdiri dari beberapa proses diantaranya adalah sebagai berikut :

1. Proses 1.0 adalah proses pengolahan data vendor yang akan langsung dihubungkan dengan tabel vendor.

2. Proses 2.0 adalah proses pengolahan data barang yang akan langsung dihubungkan dengan tabel data barang.

3. Proses 3.0 adalah proses pengolahan data pembelian yang akan langsung dihubungkan dengan tabel pembelian.

4. Proses 4.0 adalah proses pengolahan data pelanggan yang akan langsung dihubungkan dengan tabel pelanggan.

5. Proses 5.0 adalah proses pengolahan data penjualan yang akan langsung dihubungkan dengan tabel penjualan.

6. Proses 6.0 adalah proses pengolahan data permintaan barang dari outlet yang akan langsung dihubungkan dengan tabel request stock.

7. Proses 7.0 adalah proses pengolahan data pengiriman barang yang akan langsung dihubungkan dengan tabel barang pindah gudang.

8. Proses 8.0 adalah proses pengolahan data forecasting yang akan langsung dihubungkan dari tabel barang pindah gudang ke tabel forecasting.

9. Proses 9.0 adalah proses pengolahan data semua transaksi-transaksi yang akan menyimpan didalam tabel stok untuk melihat seluruh stok yang masuk dan keluar.

10. Proses 10.0 adalah proses cetak laporan yang akan mencetak laporan yang sesuai pada pihak yang membutuhkan.

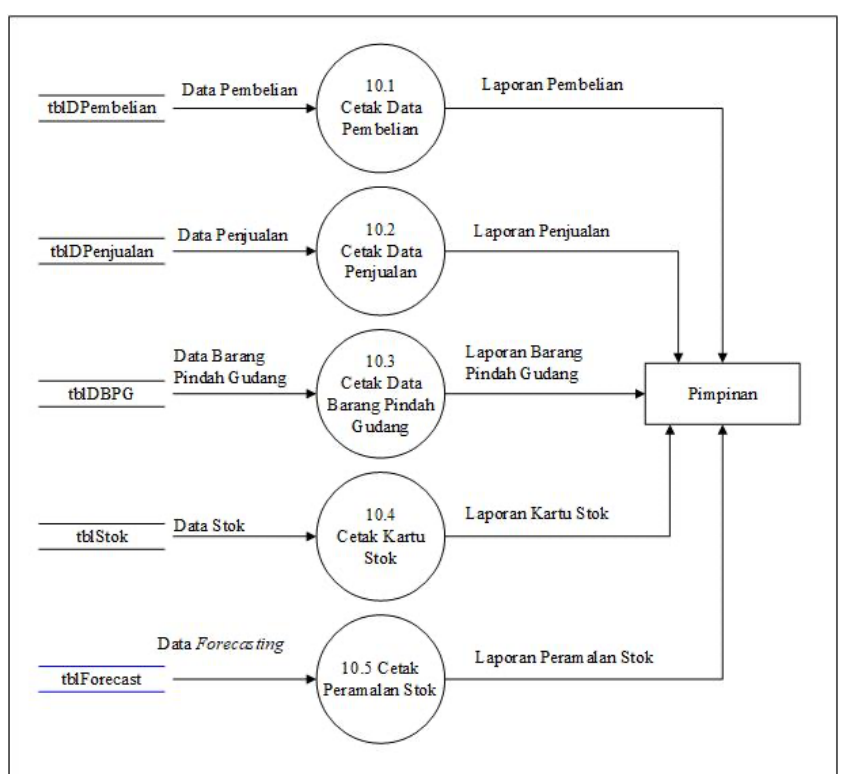

Gambar 12. Data Flow Diagram Level 1 Proses 10.0 Cetak

Dari DFD Level 10.0 terdiri dari beberapa proses diantaranya adalah sebagai berikut :

1. Proses 10.1 cetak data pembelian yaitu proses percetakan data pembelian yang terdapat didalam tabel tblPembelian.

2. Proses 10.2 cetak data penjualan yaitu proses percetakan data penjualan yang terdapat didalam tabel tblPenjualan.

3. Proses 10.3 cetak data barang pindah gudang yaitu proses percetakan data barang pindah gudang yang terdapat didalam tabel tblDBPG.

4. Proses 10.4 cetak data stok yaitu proses percetakan data kartu stok yang terdapat didalam tabel tblStok.

5. Proses 10.5 cetak data forecast yaitu proses percetakan data forecast double exponential smoothing yang terdapat didalam tabel tblForecast.

C. Perancangan Basis Data

Perancangan basis data merupakan desain dari hasil analisis yang telah dilakukan untuk memenuhi permintaanpermintaan sistem dan gambaran-gambaran perancangan proses akan dibuat dalam bentuk entity relationship diagram.

1. Entity Relationship Diagram (ERD)

Entity Relationship Diagram (ERD) atau diagram antar entitas adalah suatu diagram yang menggambarkan hubungan objek data yang disimpan yang ada dalam suatu sistem secara konseptual.

Objek data adalah objek yang dapat dicatat atau direkam atau segala sesuatu yang dapat dibedakan entitas dapat berupa orang, benda, tempat, peristiwa atau konsep yang bisa diolah untuk menghasilkan informasi, rancangan diagram entitas ini dibuat menurut data yang ada sehingga dapat menjelaskan hubungan. 


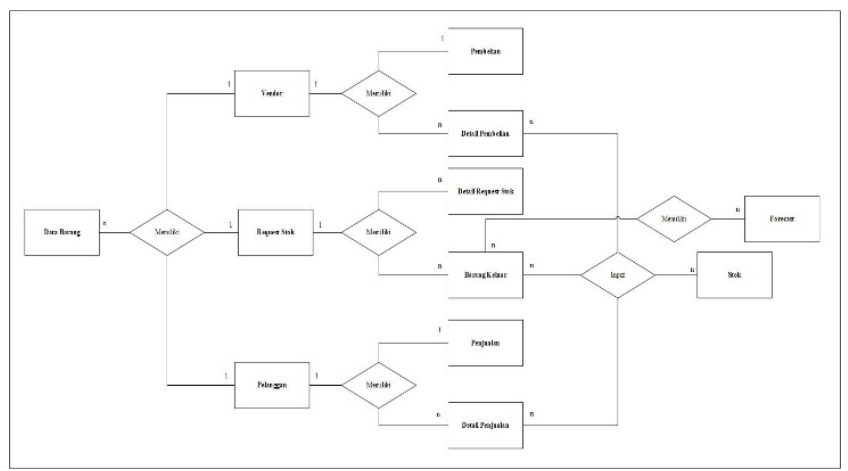

Gambar 13. Entity Relationship Diagram

2. Perancangan Struktur File

Didalam perbuatan program dibutuhkan suatu aplikasi file yang dimaksudkan untuk dapat melakukan kegiatankegiatan dalam pengaturan pencarian data dan pembuatan laporan yang dapat mempermudah kerja sistem komputer. Untuk itu sistem pengolahan data ini membutuhkan spesifikasi file untuk mempermudah dalam melakukan kegiatan pemrograman, yang dapat dilihat dari tabel-tabel berikut ini :

Tabel 2. Struktur File tblUser

\begin{tabular}{|l|l|l|}
\hline Nama Field & Tipe Data & Keterangan \\
\hline KodeUser & int & Primary Key \\
\hline NamaUser & nvarchar & \\
\hline Password & nvarchar & \\
\hline
\end{tabular}

Tabel 3. Struktur File tblPerusahaan

\begin{tabular}{|l|l|l|}
\hline Nama Field & Tipe Data & Keterangan \\
\hline NamaUsaha & text & \\
\hline Alamat & text & \\
\hline KodePos & text & \\
\hline NoTelp & text & \\
\hline Email & text & \\
\hline NamaPimpinan & text & \\
\hline
\end{tabular}

Tabel 4. Struktur File tblVendor

\begin{tabular}{|l|l|l|}
\hline Nama Field & Tipe Data & Keterangan \\
\hline Vendor & nvarchar & \\
\hline Alamat & nvarchar & \\
\hline Telp & nvarchar & \\
\hline
\end{tabular}

Tabel 5. Struktur File tblPelanggan

\begin{tabular}{|l|l|l|}
\hline Nama Field & Tipe Data & Keterangan \\
\hline Pelanggan & nvarchar & \\
\hline Alamat & nvarchar & \\
\hline
\end{tabular}

Telp nvarchar

Tabel 6. Struktur File tblDataBarang

\begin{tabular}{|l|l|l|}
\hline Nama Field & Tipe Data & Keterangan \\
\hline KodeBarang & nvarchar & Primary Key \\
\hline NamaBarang & nvarchar & \\
\hline Kelompok & nvarchar & \\
\hline Satuan & nvarchar & \\
\hline HargaBeli & numeric & \\
\hline HargaJual & numeric & \\
\hline
\end{tabular}

Tabel 7. Struktur File tblHPembelian

\begin{tabular}{|l|l|l|}
\hline Nama Field & Tipe Data & Keterangan \\
\hline NoInvoice & nvarchar & Primary Key \\
\hline Vendor & nvarchar & \\
\hline Gudang & nvarchar & \\
\hline Tanggal & date & \\
\hline NilaiInvoice & numeric & \\
\hline
\end{tabular}

Tabel 8. Struktur File tblDPembelian

\begin{tabular}{|l|l|l|}
\hline Nama Field & Tipe Data & Keterangan \\
\hline NoInvoice & nvarchar & \\
\hline Vendor & nvarchar & \\
\hline Gudang & nvarchar & \\
\hline Tanggal & date & \\
\hline KodeBarang & nvarchar & \\
\hline NamaBarang & nvarchar & \\
\hline Qty & nvarchar & \\
\hline Satuan & nvarchar & \\
\hline HargaBeli & numeric & \\
\hline Total & numeric & \\
\hline
\end{tabular}

Tabel 9. Struktur File tblHPenjualan

\begin{tabular}{|l|l|l|}
\hline Nama Field & Tipe Data & Keterangan \\
\hline NoInvoice & nvarchar & Primary Key \\
\hline Pelanggan & nvarchar & \\
\hline Gudang & nvarchar & \\
\hline Tanggal & date & \\
\hline NilaiInvoice & numeric & \\
\hline
\end{tabular}


Tabel 10. Struktur File tblDPenjualan

\begin{tabular}{|l|l|l|}
\hline Nama Field & Tipe Data & Keterangan \\
\hline NoInvoice & nvarchar & \\
\hline Pelanggan & nvarchar & \\
\hline Gudang & nvarchar & \\
\hline Tanggal & date & \\
\hline KodeBarang & nvarchar & \\
\hline NamaBarang & nvarchar & \\
\hline Qty & nvarchar & \\
\hline Satuan & nvarchar & \\
\hline HargaJual & numeric & \\
\hline Total & numeric & \\
\hline
\end{tabular}

Tabel 11. Struktur File tblReqStok

\begin{tabular}{|l|l|l|}
\hline Nama Field & Tipe Data & Keterangan \\
\hline NoBPG & nvarchar & Primary Key \\
\hline DrGudang & nvarchar & \\
\hline KeGudang & nvarchar & \\
\hline Tanggal & date & \\
\hline
\end{tabular}

Tabel 12. Struktur File tblDReqStok

\begin{tabular}{|l|l|l|}
\hline Nama Field & Tipe Data & Keterangan \\
\hline NoBPG & nvarchar & \\
\hline DrGudang & nvarchar & \\
\hline KeGudang & nvarchar & \\
\hline Tanggal & date & \\
\hline KodeBarang & nvarchar & \\
\hline NamaBarang & nvarchar & \\
\hline Qty & int & \\
\hline Satuan & nvarchar & \\
\hline
\end{tabular}

Tabel 13. Struktur File tblDBPG

\begin{tabular}{|l|l|l|}
\hline Nama Field & Tipe Data & Keterangan \\
\hline NoBPG & nvarchar & \\
\hline DrGudang & nvarchar & \\
\hline KeGudang & nvarchar & \\
\hline Tanggal & date & \\
\hline KodeBarang & nvarchar & \\
\hline NamaBarang & nvarchar & \\
\hline Qty & int & \\
\hline Satuan & nvarchar & \\
\hline
\end{tabular}

Tabel 14. Struktur File

\begin{tabular}{|l|l|l|}
\hline Nama Field & Tipe Data & Keterangan \\
\hline NoTransaksi & nvarchar & \\
\hline Tanggal & date & \\
\hline Gudang & nvarchar & \\
\hline KodeBarang & nvarchar & \\
\hline NamaBarang & nvarchar & \\
\hline Masuk & int & \\
\hline Keluar & int & \\
\hline
\end{tabular}

D. Perancangan Antarmuka

Perancangan antarmuka merupakan desain dari hasil analisa yang telah dilakukan untuk memenuhi permintaanpermintaan sistem dan gambaran-gambaran perancangan proses akan dibuat dalam bentuk perancangan struktur program, perancangan struktur menu, rancangan input dan rancangan output.

1. Perancangan Struktur Program

Struktur program adalah suatu konsep pembuatan yang mempunyai fungsi untuk mengelompokan intruksi kedalam sub program fungsional dimana setiap sub program tersebut memiliki tugas dan fungsi tertentu yang digunakan untuk mendukung dari keseluruhan program yang dibuat. Struktur program yang dibuat adalah sebagai berikut :

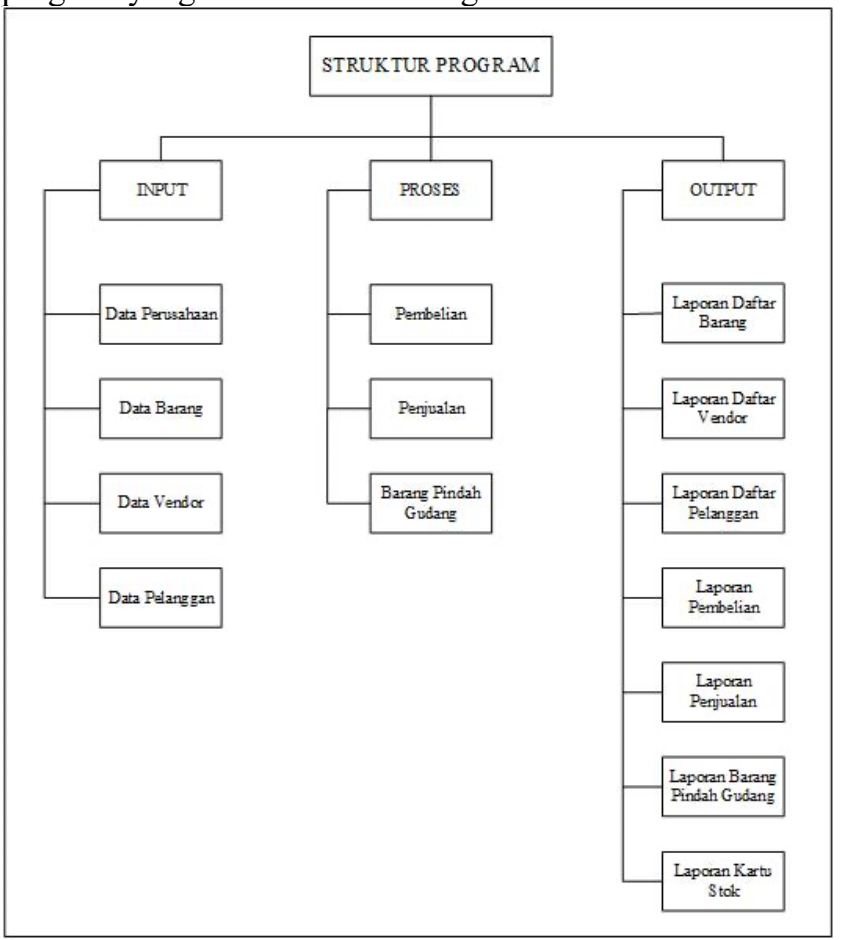

Gambar 14. Struktur Program

2. Perancangan Struktur Menu

Struktur menu membentuk umum dalam suatu perancangan aplikasi yang dapat memudahkan pengguna 
dalam menggunakan sistem yang dibangun. Dengan adanya struktur menu ini maka proses pengolahan data diharapkan lebih cepat dilakukan, sehingga keterlambatan dalam penyajian data dapat ditekan seminimal mungkin.

Struktur menu yang dibuat dalam sistem ini terdiri dari menu-menu dan submenu nya. Dapat dilihat dari gambar berikut :

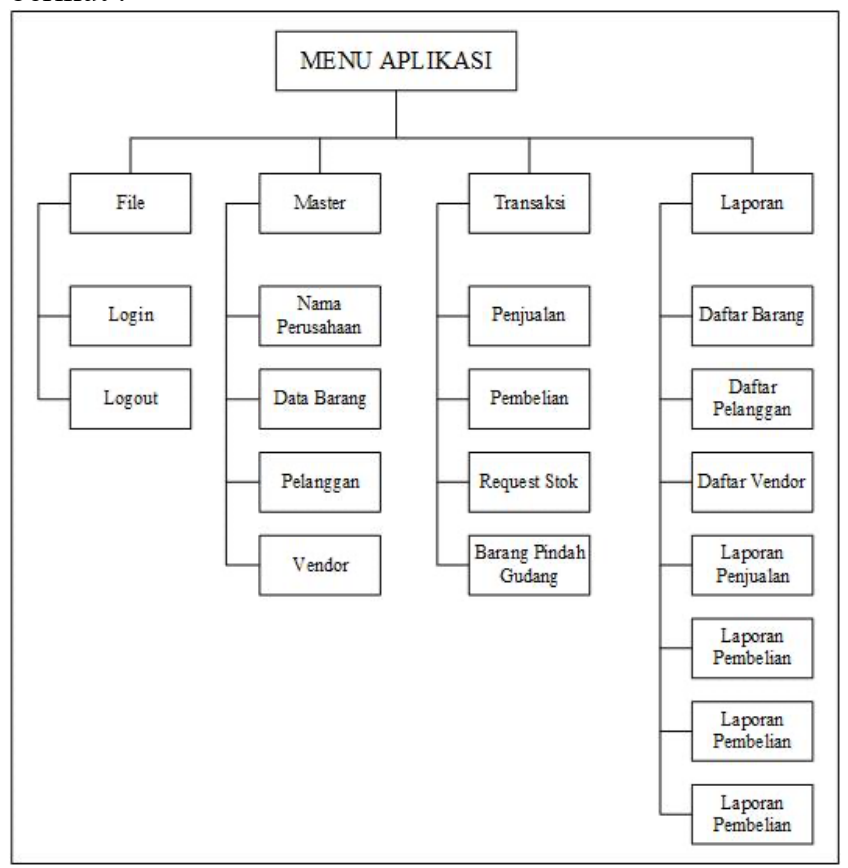

Gambar 15. Struktur Menu

3. Rancangan Input

Rancangan input adalah rancangan dari dokumen dasar yang digunakan untuk rekap data yang digunakan. Perancangan input meliputi bentuk dokumen-dokumen input yang akan digunakan untuk menangkap data input.

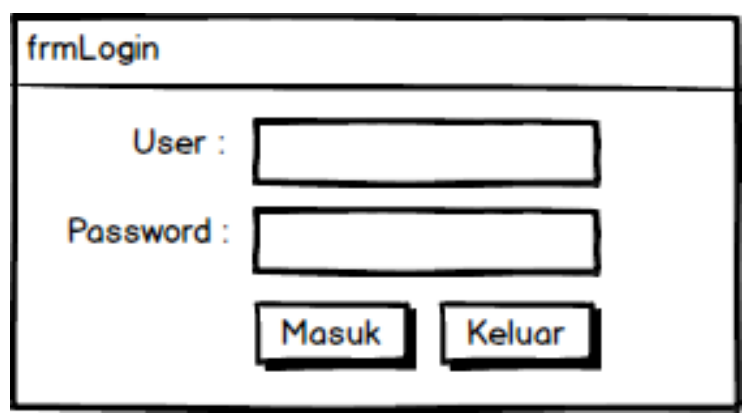

Gambar 16. Rancangan Input Login

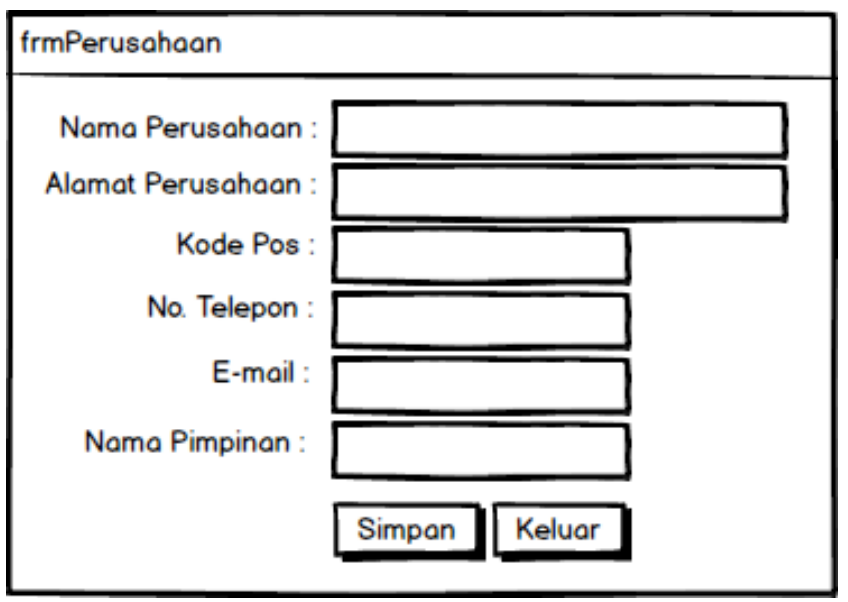

Gambar 17. Rancangan Input Master Perusahaan

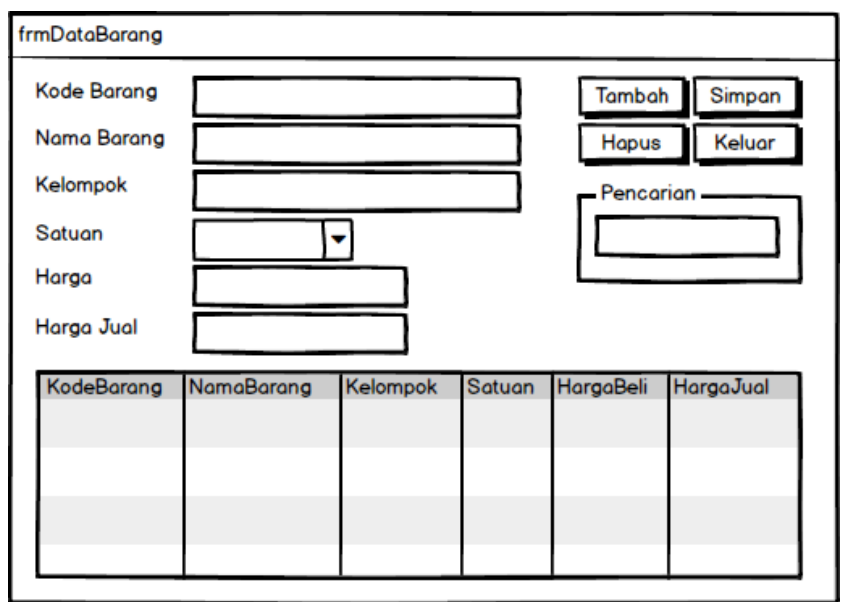

Gambar 18. Rancangan Input Data Barang

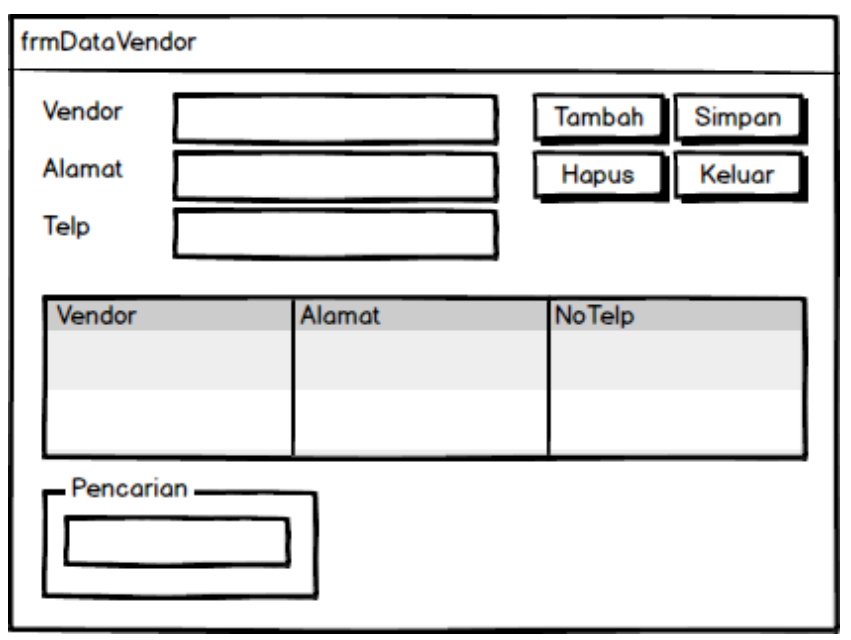

Gambar 19. Rancangan Input Data Vendor 


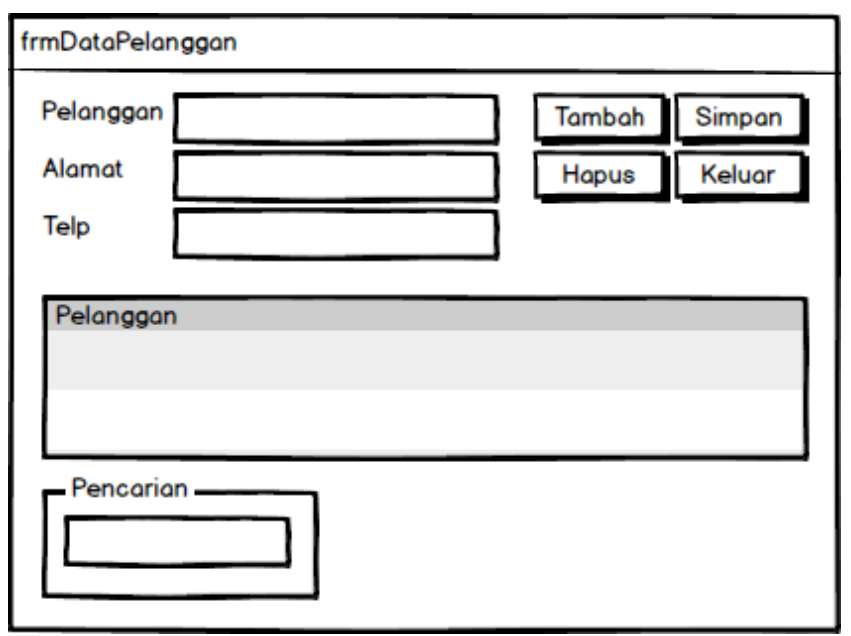

Gambar 20. Rancangan Input Data Pelanggan

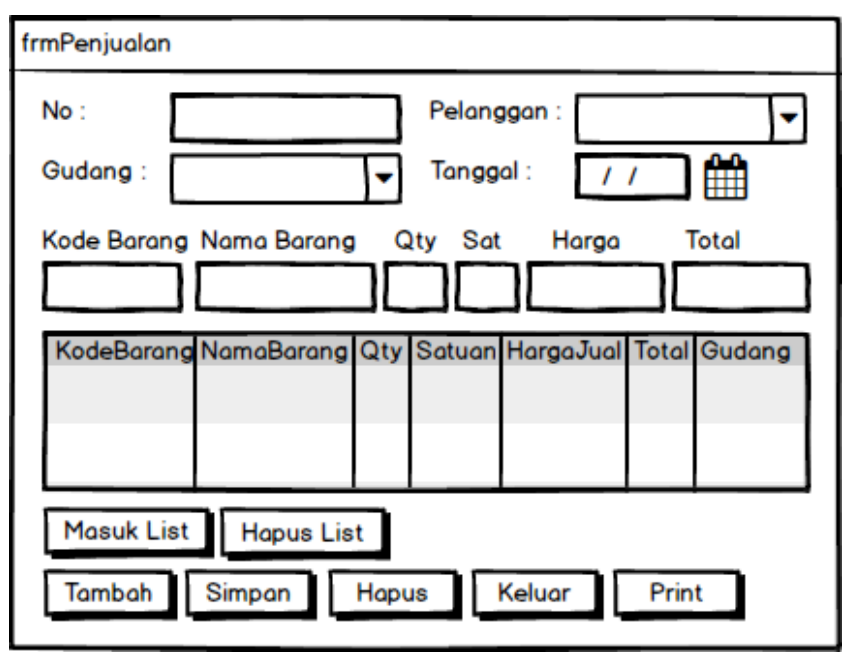

Gambar 21. Rancangan Input Penjualan

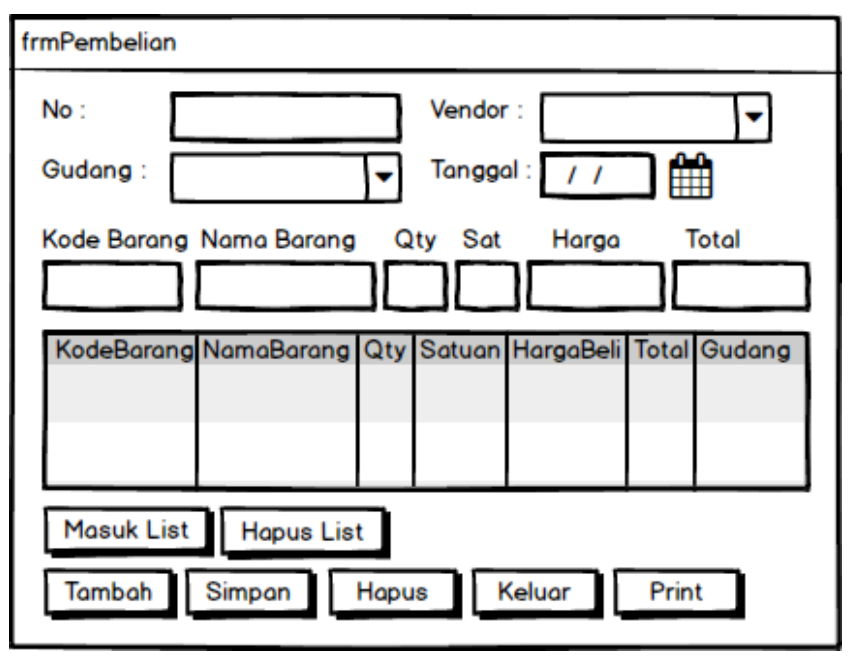

Gambar 22. Rancangan Input Pembelian

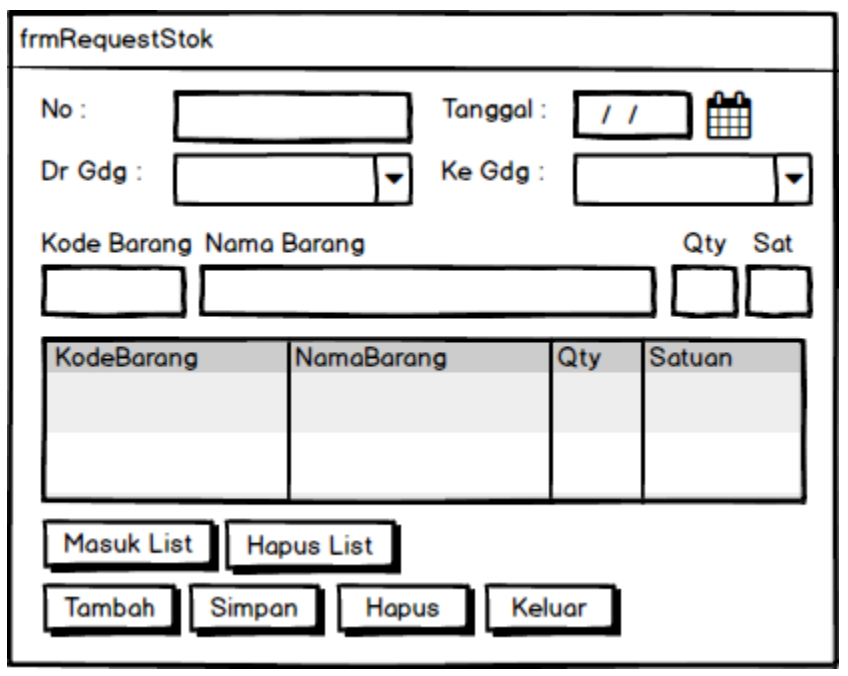

Gambar 23. Rancangan Input Request Stok



Gambar 24. Rancangan Input Barang Pindah Gudang

\section{Rancangan Output}

Rancangan output adalah rancangan dalam bentuk laporan dari hasil pemrosesan input yang diterima dari sistem pengolahan data tersebut. Untuk menentukan rancangan output diperlukan kecermatan, ketelitian dan kesabaran dengan harapan output yang dihasilkan merupakan laporan-laporan yang akurat dan relawan serta dapat dimengertikan oleh penggunanya. 


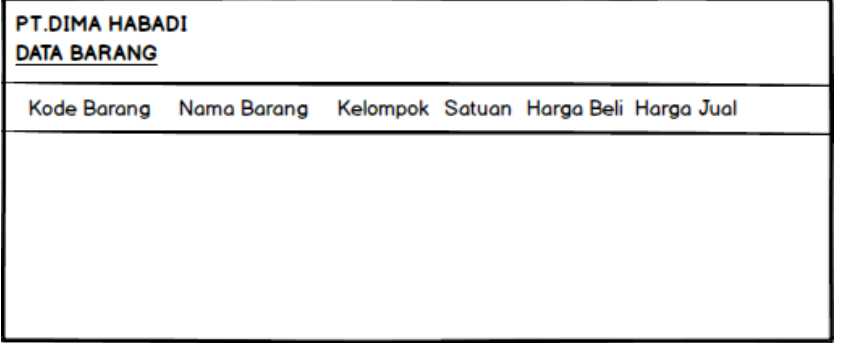

Gambar 25. Rancangan Output Laporan Daftar Barang

\begin{tabular}{|l|}
\hline $\begin{array}{l}\text { PT.DIMA HABADI } \\
\text { OATA PELANGGAN }\end{array}$ \\
\hline Pelonggan Alamat $\quad$ Telp \\
\hline \\
\\
\\
\\
\\
\end{tabular}

Gambar 26. Rancangan Output Laporan Daftar Pelanggan

\begin{tabular}{|l|}
\hline $\begin{array}{l}\text { PT.DIMA HABADI } \\
\text { DATA VENDOR }\end{array}$ \\
\hline Vendor Alamat $\quad$ Telp \\
\hline \\
\\
\end{tabular}

Gambar 27. Rancangan Output Laporan Daftar Vendor

\begin{tabular}{|c|c|c|c|}
\hline \multicolumn{4}{|c|}{$\begin{array}{l}\text { PT.DIMA HABADI } \\
\text { LAPORAN PENJUALAN PER INVOICE } \\
\text { PERIODE - PERIODE }\end{array}$} \\
\hline TANGGAL & PELANGGAN & NO INVOICE & NILAI \\
\hline
\end{tabular}

Gambar 28. Rancangan Output Laporan Penjualan per Invoice

\begin{tabular}{|c|c|c|c|}
\hline \multicolumn{4}{|c|}{$\begin{array}{l}\text { PT.DIMA HABADI } \\
\text { LAPORAN PENJUALAN PER BARANG } \\
\text { PERIODE - PERIODE }\end{array}$} \\
\hline NO KODE BARANG & NAMA BARANG & JUMLAH & TOTAL \\
\hline
\end{tabular}

Gambar 29. Rancangan Output Laporan Penjualan per Barang

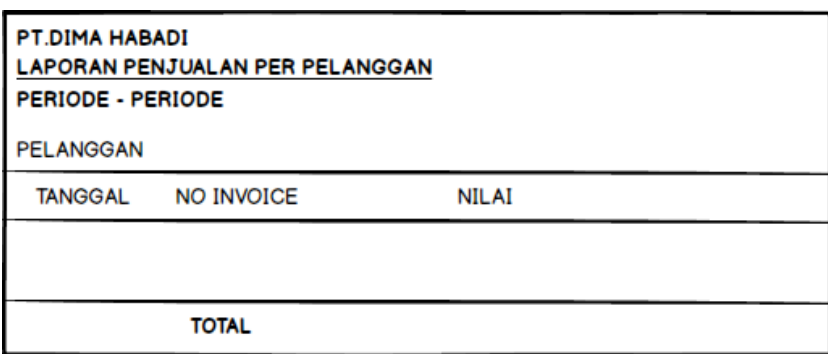

Gambar 30. Rancangan Output Laporan Penjualan per Pelanggan

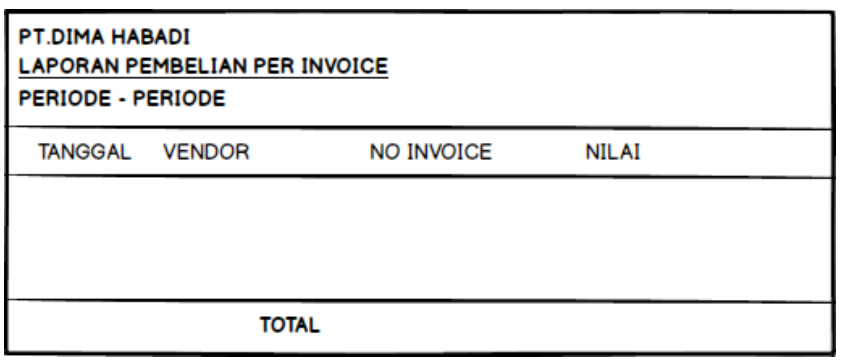

Gambar 31. Rancangan Output Laporan Pembelian per Invoice

\begin{tabular}{|c|c|c|c|}
\hline $\begin{array}{l}\text { PT.DIMA HABADI } \\
\text { LAPORAN PEMBELIA } \\
\text { PERIODE - PERIODE }\end{array}$ & PER BARANG & & \\
\hline NO KODE BARANG & NAMA BARANG & JUMLAH & TOTAL \\
\hline
\end{tabular}

Gambar 32. Rancangan Output Laporan Pembelian per Barang

\begin{tabular}{|c|c|c|}
\hline $\begin{array}{l}\text { PT.DIMA HAB } \\
\text { LAPORAN PEI } \\
\text { PERIODE - PE } \\
\text { VENDOR }\end{array}$ & $\begin{array}{l}\text { DI } \\
\text { IBELIAN PER } \\
\text { RIODE }\end{array}$ & \\
\hline TANGGAL & NO INVOICE & NILAI \\
\hline
\end{tabular}

Gambar 33. Rancangan Output Laporan Pembelian per Vendor

\section{PT.DIMA HABADI}

LAPORAN BARANG PINDAH GUDANG

PERIODE - PERIODE

$\begin{array}{ll}\text { No: } & \text { Dari Gudang: } \\ \text { Tanggal : } & \text { Ke Gudang }\end{array}$

Kode Barang NamaBarang Request Kirim Selisih

Gambar 34. Rancangan Output Laporan Barang Pindah Gudang 


\begin{tabular}{|c|c|c|c|c|}
\hline \multicolumn{5}{|l|}{$\begin{array}{l}\text { PT.DIMA HABADI } \\
\text { LAPORAN KARTU STOK } \\
\text { PERIODE - PERIODE }\end{array}$} \\
\hline \multicolumn{5}{|c|}{ Gudang } \\
\hline \multicolumn{5}{|l|}{ KodeBarang NamaBarang } \\
\hline TANGGAL NO TRANSAKSI & AWAL & MASUK & KELUAR & AKHIR \\
\hline
\end{tabular}

Gambar 35. Rancangan Output Laporan Kartu Stok

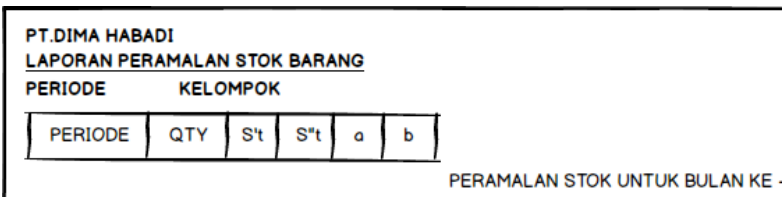

Gambar 36. Rancangan Output Laporan Peramalan Stok

\begin{tabular}{|llll|}
\hline PT.DIMA HABADI & \multicolumn{1}{l|}{ INVOICE } & & \\
INVOICE NO: & & & \\
TANGGAL: & KEPADA : & \\
\hline NO KODE BARANG NAMA BARANG & JUMLAH & HARGA JUAL & TOTAL \\
\hline & & & \\
\hline & & & Grand Total \\
\hline
\end{tabular}

Gambar 37. Rancangan Output Penjualan

\begin{tabular}{|llll|}
\hline $\begin{array}{l}\text { PT.DIMA HABADI } \\
\text { PEMBELIAN } \\
\text { NO INVOICE } \\
\text { TANGGAL }\end{array}$ & & & \\
\hline NO KODE BARANG NAMA BARANG & JUMLAH & HARGA JUAL & TOTAL \\
\hline & & & \\
\hline & & & \\
\hline & & Grand Total & \\
\hline
\end{tabular}

Gambar 38. Rancangan Output Pembelian

\section{IMPLEMENTASI SISTEM}

Aplikasi setelah dianalisa dan dirancang, maka aplikasi tersebut siap diterapkan atau diimplementasikan. Tahap implementasi aplikasi ini merupakan tahap meletakkan perancangan aplikasi ke dalam bentuk coding Bahasa pemrograman.

Dalam rencana implementasi aplikasi ada empat landasan yang akan dikemukakan yaitu :

1. Penjadwalan waktu kegiatan yang akan dilakukan dalam pembangunan aplikasi.

2. Mengalokasikan sumber-sumber dan keahlian yang diperlukan untuk pelaksanaan kegiatan.

3. Menentukan waktu pelaksanaan untuk setiap kegiatan.
4. Menentukan urutan pelaksanaan kegiatan yang telah diidentifikasi.

Kegiatan implementasi ini meliputi kebutuhan perangkat lunak, perangkat keras, pemilihan bahasa pemrograman yang sesuai, teknik pemrograman dan pengujian sistem dan program yang telah dirancang sesuai dengan kebutuhan instansi atau perusahaan.

\section{KESIMPULAN}

Berdasarkan permasalahan yang dihadapi oleh PT.Dima Habadi dalam perhitungan stok barang per gudang, kemudian dianalisa dan dibentuk rancangan baru suatu Sistem Informasi Perhitungan Stok Barang per Gudang maka penulis dengan ini menyimpulkan bahwa membantu mempercepat dan meningkatkan efisiensi kerja pada saat pemesanan stok barang karena tidak lagi dilakukan secara perkiraan melainkan secara komputerisasi, mempermudah dan meningkatnya efisiensi waktu dalam pencarian serta pembuatan laporan-laporan yang dibutuhkan, mempermudah pengecekan barang yang masih tersedia saat adanya pembelian yang dilakukan oleh pelanggan dan diminta oleh outlet, penyimpanan data dalam bentuk database dapat mengurangi tempat penyimpanan dan dapat membantu mengurangi resiko kehilangan data, membantu meramalkan stok untuk periode berikutnya berdasarkan periode yang dibutuhkan untuk memudahkan Purchasing dalam proses pengoderan barang ke Supplier.

\section{REFERENSI}

[1]. Nugroho Adi, Analisis dan Perancangan Sistem Informasi dengan Metodologi Berorientasi Objek, Informatika, 2004, Bandung.

[2]. Hartono Jogiyanto, Pengenalan Komputer, Andi, 1999, Yogyakarta.

[3]. Sutabri Tata, Sistem Informasi Manajemen, Andi, 2005, Yogyakarta.

[4]. Rusmawan Uun, Koleksi Program VB.NET untuk Tugas Akhir dan Skripsi, PT Elex Media Komputindo, 2014, Jakarta.

[5]. Ngurah Suryantara, Gusti, S.Kom., M.Kom, Merancang Aplikasi Distributor dengan VB.NET, PT Elex Media Komputindo, 2015, Jakarta.

[6]. Nono, Kumpulan Aplikasi Berbasis VB.6, VB.NET, JAVA, PT Elex Media Komputindo, 2012, Jakarta.

[7]. Ngurah Suryantara Gusti, S.Kom., M.Kom, Merancang Aplikasi Akuntansi dengan VB.Net, PT Elex Media Komputindo, 2014, Jakarta.

[8]. Adi Pratama, Danang, "Aplikasi Metode Double Exponential Smoothing Brown dan Holt Untuk Meramalkan Total Pendapatan Bea dan Cukai", no.2, hal 3, 2016

[9]. Pujiati, Etri, "Peramalan dengan Menggunakan Metode Double Exponential Smoothing dari Brown”, Jurnal Eksponensial, no.7, hal 2, 2016

[10]. Erfan Rohadi, Mansyur, "Sistem Informasi Peramalan Stok Barang di CV.Annora Asia Menggunakan Metode Double Exponential Smoothing”, Jurnal Informatika Polinema, no.3, hal 2, 2017

[11]. Ariyanto, Rudy, "Penerapan Metode Double Exponential Smoothing pada Peramalan Produksi Tanaman Pangan", Jurnal Informatika Polinema, no.3, hal 2, 2018

[12]. Purwanto, Agus, "Teknik Peramalan dengan Double Exponential Smoothing pada Distributor Gula", Jurnal Teknologi Informasi dan Komputer, no.5, hal 3, 2017

[13]. Andriyanto, Teguh, "Sistem Peramalan Emas Antam Menggunakan Double Exponential Smoothing", Jurnal Intensif, no.1, hal 2, 2017

[14]. Yulia Hayuningtyas, Ratih, "Peramalan Persediaan Barang Menggunakan Metode Weighted Moving Average dan Metode Double Exponential Smoothing”, no.2, hal 2, 2017 
Bangkit Indonesia, Vol. VIII, No. 01, Bulan Maret 2019

[15]. Victor Imbar, Radiant, "Aplikasi Peramalan Stok Barang Menggunakan Metode Double Exponential Smoothing", Jurnal Sistem Informasi, no.7, hal 5, 2012

[16]. Wahyu Anang, Abet, "Penerapan Metode Double Exponential Smoothing untuk Estimasi Hasil Penjualan", Jurnal Teknik Informatika, no.6, hal.15, 2012

[17]. Riska Perdana, Fajar, Perbandingan Metode Double Expenential Smoothing dengan Triple Exponential Smoothing pada Peramalan Penjualan Rokok", no.3, hal 3 